\title{
Sludge Batch 7b Qualification Activities With SRS Tank Farm Sludge
}

J. M. Pareizs
A. L. Billings
S. H. Reboul
D. P. Lambert
D. R. Click

November 2011

Savannah River National Laboratory

Savannah River Nuclear Solutions, LLC Aiken, SC 29808

Prepared for the U.S. Department of Energy under contract number DE-AC09-08SR22470.

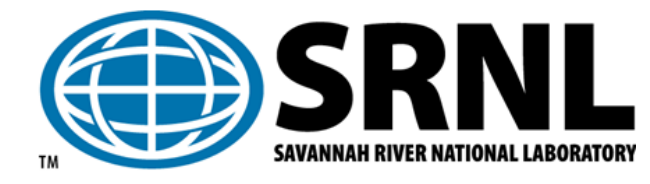


SRNL-STI-2011-00548

Revision 0

\section{DISCLAIMER}

This work was prepared under an agreement with and funded by the U.S. Government. Neither the U.S. Government or its employees, nor any of its contractors, subcontractors or their employees, makes any express or implied:

1. warranty or assumes any legal liability for the accuracy, completeness, or for the use or results of such use of any information, product, or process disclosed; or

2. representation that such use or results of such use would not infringe privately owned rights; or

3. endorsement or recommendation of any specifically identified commercial product, process, or service.

Any views and opinions of authors expressed in this work do not necessarily state or reflect those of the United States Government, or its contractors, or subcontractors.

\section{Printed in the United States of America \\ Prepared for \\ U.S. Department of Energy}


Keywords: $D W P F$, Qualification, Sludge Batch, Tank Farm

Retention: Permanent

\section{Sludge Batch 7b Qualification Activities With SRS Tank Farm Sludge}

J. M. Pareizs
A. L. Billings
S. H. Reboul
D. P. Lambert
D. R. Click

November 2011

Savannah River National Laboratory

Savannah River Nuclear Solutions, LLC Aiken, SC 29808

Prepared for the U.S. Department of Energy under contract number DE-AC09-08SR22470.

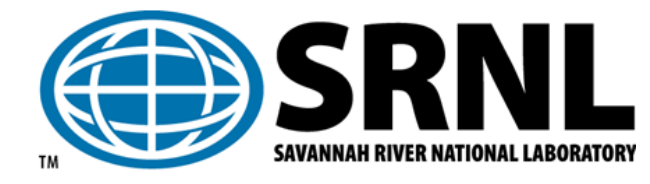




\section{REVIEWS AND APPROVALS}

AUTHORS:

J. M. Pareizs, Process Technology Programs

A. L. Billings, Process Technology Programs

S. H. Reboul, Process Technology Programs

D. P. Lambert, Process Technology Programs

D. R. Click, Spectroscopy and Separations

TECHNICAL REVIEW:

D. C. Koopman, Process Technology Programs

D. K. Peeler, Process Technology Programs

APPROVAL:

C. C. Herman, Manager

Process Technology Programs

S. L. Marra, Manager

Date

Environmental \& Chemical Process Technology Research Programs

J. E. Occhipinti, Manager

Waste Solidification Engineering
Date

Date

Date

Date

Date
Date

Date

ate 


\section{ACKNOWLEDGEMENTS}

The authors would like to recognize the invaluable support of the Savannah River National Laboratory (SRNL) Shielded Cells technicians and management for the in-cells work; SRNLAnalytical Development (AD) researchers and technicians for all other analyses; T. B. Edwards of the SRNL Statistical Consultation group for statistical analysis support; and Michael Stone and personnel from the SRNL Glass Shop for design and fabrication of the processing equipment. 


\section{EXECUTIVE SUMMARY}

Waste Solidification Engineering (WSE) has requested that characterization and a radioactive demonstration of the next batch of sludge slurry - Sludge Batch 7b (SB7b) - be completed in the Shielded Cells Facility of the Savannah River National Laboratory (SRNL). This characterization and demonstration, or sludge batch qualification process, is required prior to transfer of the sludge from Tank 51 to the Defense Waste Processing Facility (DWPF) feed tank (Tank 40). Typically, SRNL receives a qualification sample from Tank 51 and washes that sample per Tank Farm plans and projections. With the tight schedule constraints for Sludge Batch 7b (SB7b) and the potential need for caustic addition to allow for an acceptable glass processing window, the qualification for $\mathrm{SB} 7 \mathrm{~b}$ was approached differently than past batches. For SB7b, SRNL prepared a Tank 51 and a Tank 40 sample for qualification. Due to schedule constraints, SRNL did not receive the qualification sample from Tank 51 nor did it simulate all of the Tank Farm washing and decanting operations. Instead, SRNL prepared a Tank 51 SB7b sample from samples of Tank 7 and Tank 51, along with a wash solution to adjust the supernatant composition to the final SB7b Tank 51 Tank Farm projections. SRNL then prepared a sample to represent SB7b in Tank 40 by combining portions of the SRNL-prepared Tank 51 SB7b sample and a Tank 40 Sludge Batch 7a (SB7a) sample. The blended sample was 71\% Tank 40 (SB7a) and 29\% Tank 7/Tank 51 on an insoluble solids basis. This sample is referred to as the SB7b Qualification Sample. The blend represented the highest projected Tank 40 heel (as of May 25, 2011), and thus, the highest projected noble metals content for SB7b. Characterization was performed on the Tank 51 SB7b samples and SRNL performed DWPF simulations using the Tank 40 SB7b material.

This report documents:

- The preparation and characterization of the Tank 51 SB7b and Tank 40 SB7b samples.

- The performance of a DWPF Chemical Process Cell (CPC) simulation using the SB7b Tank 40 sample. The simulation included a Sludge Receipt and Adjustment Tank (SRAT) cycle, where acid was added to the sludge to destroy nitrite and reduce mercury, and a Slurry Mix Evaporator (SME) cycle, where glass frit was added to the sludge in preparation for vitrification. The SME cycle also included replication of five canister decontamination additions and concentrations. Processing parameters were based on work with a nonradioactive simulant.

- Vitrification of a portion of the SME product and characterization and durability testing (as measured by the Product Consistency Test (PCT)) of the resulting glass.

- Rheology measurements of the SRAT receipt, SRAT product, and SME product.

Key observations, conclusions, and recommendations from this work include:

- Characterization of the Tank 51 SB7b did not identify any new reportable elements or radionuclides.

- Rheological properties were acceptable for SRAT receipt and SRAT product. However, the measured yield stresses were near the upper operating limits for DWPF processing and the material appeared to be very tacky/sticky. At $>46 \mathrm{wt} \%$ total solids, the SME product had a very high consistency. It is recommended that DWPF not concentrate to this level. 
- Potential error in the analytical inputs resulted in the need to add additional acid and re-boil the SRAT to meet the nitrite destruction limit. After the third addition and boiling cycle, the SB7b Tank 40 qualification sample as prepared by SRNL met the processing constraints imposed by the DWPF. Mercury was removed to DWPF target levels after the first addition and boiling cycle (nominally 12 hours). Hydrogen generation rates were below the DWPF design bases throughout the SRAT and SME cycles.

- Foaming was not problematic during SRAT and SME processing, and antifoam was effective when added. The antifoam was from Siovation Lot\#111128-0613. 300 ppm antifoam was added prior to acid addition; $100 \mathrm{ppm}$ antifoam was added after the initial nitric acid addition; $500 \mathrm{ppm}$ antifoam was added prior to boiling in Stage 1; $100 \mathrm{ppm}$ additions were made at the start of each additional stage of acid addition; and a $100 \mathrm{ppm}$ addition was made prior to the first frit/formic acid addition.

- The SB7b SME product (SB7b Tank 40 Qualification sludge plus Frit 702) was used to fabricate a glass with a targeted waste loading of $36 \%$. The glass was acceptable with respect to chemical durability as measured by the PCT. Specifically, the SB7b glass had a normalized boron release of $0.77 \mathrm{~g} / \mathrm{L}$, while the Environmental Assessment (EA) glass had a normalized release of $16.6 \mathrm{~g} / \mathrm{L}$. The PCT response was also predictable by the current durability models of the DWPF Product Composition Control System (PCCS). 


\section{TABLE OF CONTENTS}

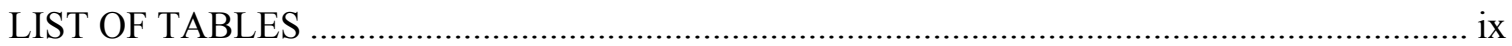

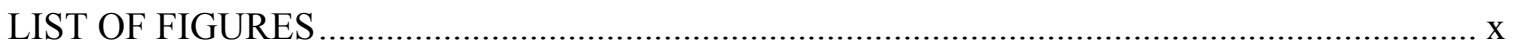

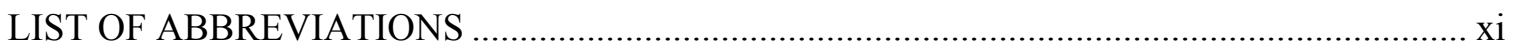

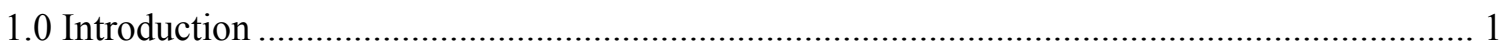

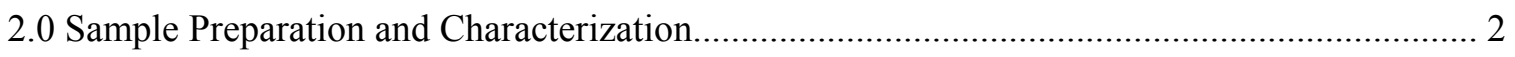

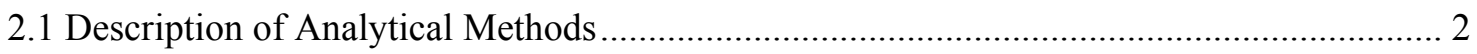

2.2 As-Received Characterization Results........................................................................ 5

2.3 Preparation and Characterization of SRNL-Prepared Sludge Batch 7b Qualification

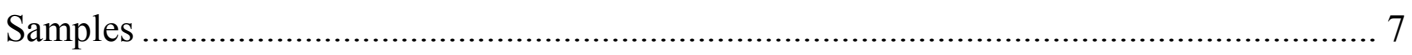

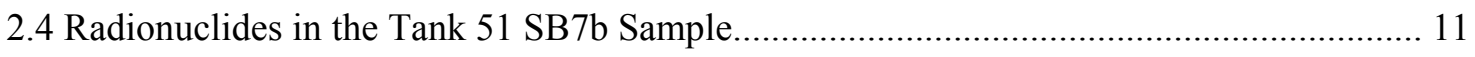

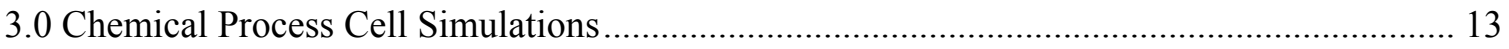

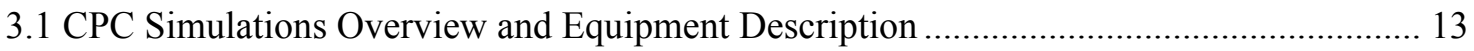

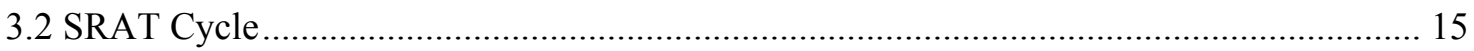

3.2.1 SRAT Receipt Characterization and Acid Calculation .............................................. 15

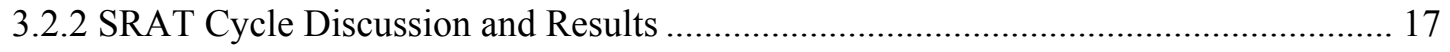

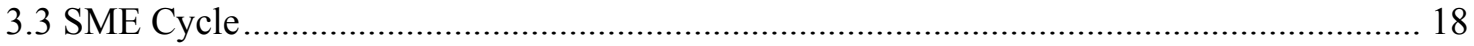

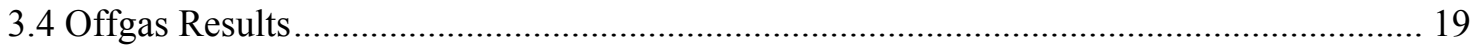

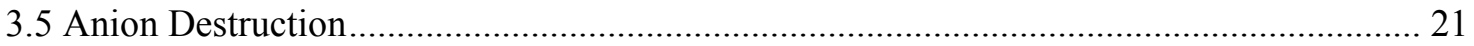

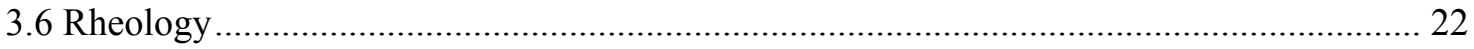

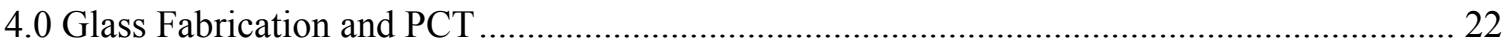

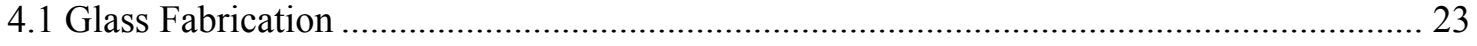

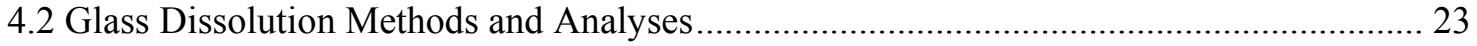

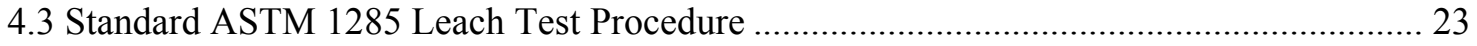

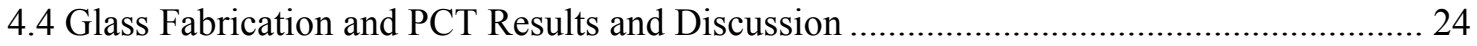

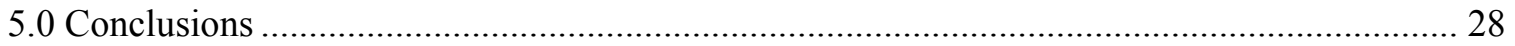

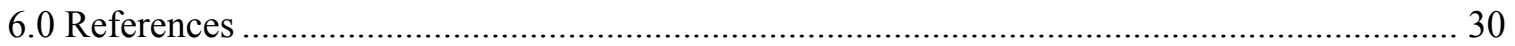

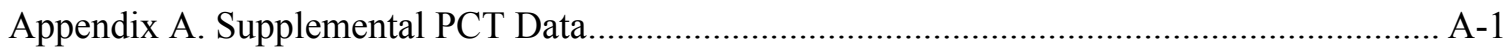

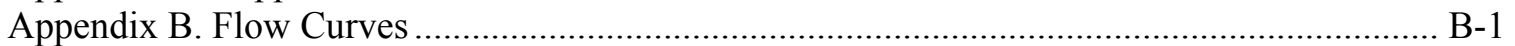




\section{LIST OF TABLES}

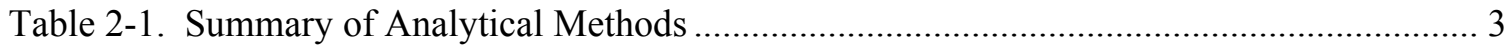

Table 2-2. MV I and MV II Rotor Specifications and Flow Curve Program ................................ 5

Table 2-3. As-Received Tank 7, Tank 40, and Tank 51 Density and Wt \% Solids Results........... 5

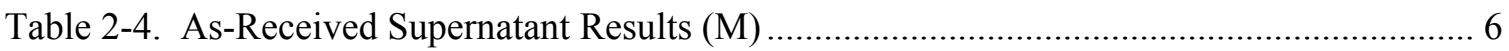

Table 2-5. As-Received Elemental Composition Results (wt \% in Total Solids) ......................... 7

Table 2-6. Analytical Results of the SRNL-Washed Tank 51 SB7a Confirmation Sample .......... 8

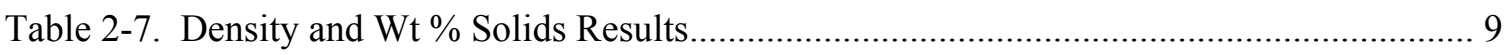

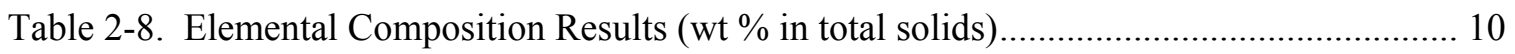

Table 2-9. Tank 51 SB7b ant Tank 40 SB7b Supernatant Results (M)..................................... 11

Table 2-10. Mean Concentrations of Radionuclides in the SB7b Qualification Sample ............. 12

Table 2-11. Fissile Isotope Analytical Results for Each of the Four Replicates (Reported to Three Digits for Purposes of Comparison) ....................................................................... 13

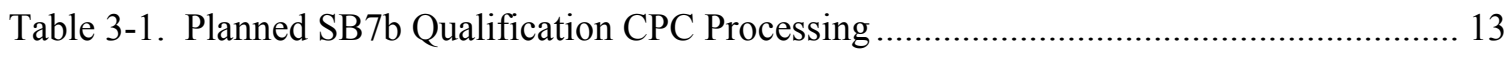

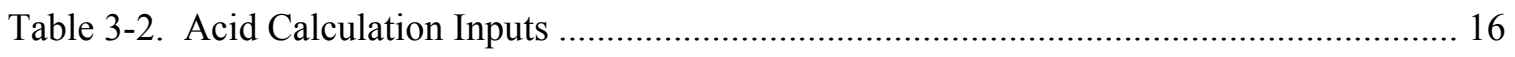

Table 3-3. Acid Calculation Results Based on One Liter of SRAT Receipt ............................... 17

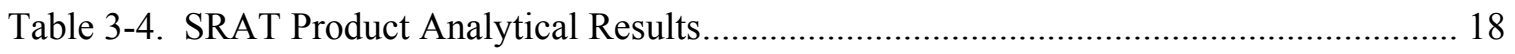

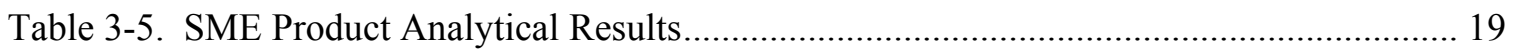

Table 3-6. SRAT Cycle Peak Gas Concentrations and Generation Rates.................................... 19

Table 3-7. SME Cycle Peak Gas Concentrations and Generation Rates..................................... 19

Table 3-8. Cumulative Anion Destruction and Conversion .................................................... 21

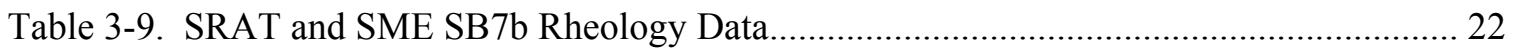

Table 4-1. Determined Oxide Concentrations Measured in SB7b Qualification Glass ............... 25

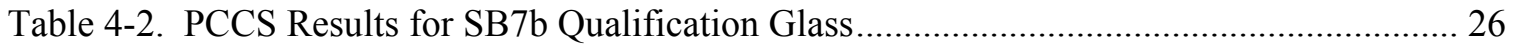

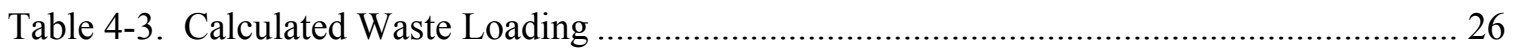

Table 4-4. PCT Results for ARM, EA and the SB7b Qualification Glass ................................. 27

Table A-1. PCT Elemental Releases and Measured $\mathrm{pH}$ for ARM, EA and the SB7b Qualification Glass. 


\section{LIST OF FIGURES}

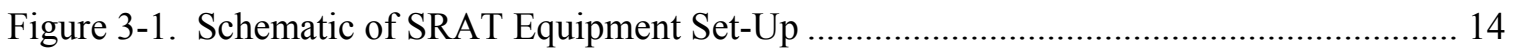

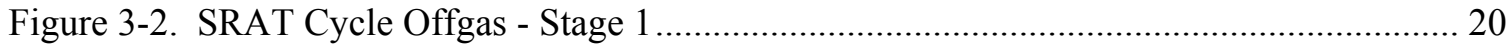

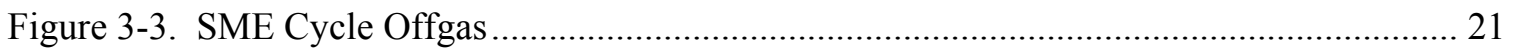

Figure 4-1. Fit of $\log$ Normalized Release of B, Li, Na and $\mathrm{Si}(\mathrm{g} / / \mathrm{L})$ vs. $\Delta \mathrm{G}_{\mathrm{p}}$ for the measured releases of ARM, EA and the SB7b Qualification glasses. ................................. 28

Figure B-1. SB7b SRAT Receipt Flow Curves...................................................................... B-2

Figure B-2. SB7b SRAT Product Flow Curves................................................................ B-3

Figure B-3. SB7b SME Product Flow Curve …...................................................................... B-4 


\section{LIST OF ABBREVIATIONS}

$\begin{array}{ll}\text { AD } & \text { SRNL Analytical Development } \\ \text { AR } & \text { aqua regia } \\ \text { ARG-1 } & \text { Analytical Reference Glass-1 } \\ \text { ARM } & \text { Analytical Reference Material } \\ \text { CPC } & \text { Chemical Process Cell } \\ \text { CVAA } & \text { cold vapor-atomic absorption } \\ \text { DWPF } & \text { Defense Waste Processing Facility } \\ \text { EA } & \text { Environmental Assessment } \\ \text { FAVC } & \text { Formic Acid Vent Condenser } \\ \text { GC } & \text { micro gas chromatograph } \\ \text { IC } & \text { ion chromatography } \\ \text { ICP-AES } & \text { inductively coupled plasma atomic emission spectroscopy } \\ \text { ICP-MS } & \text { inductively coupled plasma mass spectroscopy } \\ \text { LEPS } & \text { low energy photon spectroscopy } \\ \text { LSC } & \text { liquid scintillation counting } \\ \text { MAR } & \text { Measurement Acceptability Region } \\ \text { MWWT } & \text { Mercury Water Wash Tank } \\ \text { NA } & \text { not applicable } \\ \text { NM } & \text { not measured } \\ \text { PCCS } & \text { Product Consistency Control System } \\ \text { PCT } & \text { Product Consistency Test } \\ \text { PF } & \text { peroxide fusion } \\ \text { R\&D } & \text { research and development } \\ \text { REDOX } & \text { reduction-oxidation (Fe'/ } \text { Fe in this document) } \\ \text { SB7a } & \text { Sludge Batch 7a } \\ \text { SB7b } & \text { Sludge Batch 7b } \\ \text { SME } & \text { Slurry Mix Evaporator } \\ \text { SMECT } & \text { Slurry Mix Evaporator Condensate Tank } \\ \text { SRAT } & \text { Sludge Receipt and Adjustment Tank } \\ \text { SRNL } & \text { Savannah River National Laboratory } \\ \text { TIC } & \text { total inorganic carbon } \\ \text { TTQAP } & \text { Task Technical and Quality Assurance Plan } \\ \text { TTR } & \text { Technical Task Request } \\ \text { WAPS } & \text { Waste Acceptance Product Specification } \\ \text { WSE } & \text { Waste Solidification Engineering } \\ \alpha-P H A ~ & \text { alpha pulse height analysis } \\ \gamma \text {-PHA } & \text { gamma pulse height analysis } \\ & \end{array}$




\subsection{Introduction}

Waste Solidification Engineering (WSE) has requested that characterization and a radioactive demonstration of the next batch of sludge slurry - Sludge Batch 7b (SB7b) - be completed in the Shielded Cells Facility of the Savannah River National Laboratory (SRNL) via a Technical Task Request (TTR). ${ }^{1}$ This characterization and demonstration, or sludge batch qualification process, is required prior to transfer of the sludge from Tank 51 to the Defense Waste Processing Facility (DWPF) feed tank (Tank 40). The current WSE practice is to prepare sludge batches in Tank 51 by transferring sludge from other tanks. Discharges of nuclear materials from $\mathrm{H}$ Canyon are often added to Tank 51 during sludge batch preparation. The sludge is washed and transferred to Tank 40, the current DWPF feed tank. Prior to transfer of Tank 51 to Tank 40, SRNL typically simulates the Tank Farm and DWPF processes with a Tank 51 sample (referred to as the qualification sample). With the tight schedule constraints for SB7b and the potential need for caustic addition to allow for an acceptable glass processing window, the qualification for SB7b was approached differently than past batches. For SB7b, SRNL prepared a Tank 51 and a Tank 40 sample for qualification. SRNL did not receive the qualification sample from Tank 51 nor did it simulate all of the Tank Farm washing and decanting operations. Instead, SRNL prepared a Tank 51 SB7b sample from samples of Tank 7 and Tank 51, along with a wash solution to adjust the supernatant composition to the final SB7b Tank 51 Tank Farm projections. SRNL then prepared a sample to represent SB7b in Tank 40 by combining portions of the SRNL-prepared Tank 51 SB7b sample and a Tank 40 Sludge Batch 7a (SB7a) sample. The blended sample was $71 \%$ Tank 40 (SB7a) and 29\% Tank 7/Tank 51 on an insoluble solids basis. This sample is referred to as the SB7b Qualification Sample. The blend represented the highest projected Tank 40 heel (as of May 25, 2011), and thus, the highest projected noble metals content for SB7b. Characterization was performed on the Tank 51 SB7b samples and SRNL performed DWPF simulations using the Tank 40 SB7b material.

This report documents:

- The preparation and characterization of the Tank 51 SB7b and Tank 40 SB7b samples.

- The performance of a DWPF Chemical Process Cell (CPC) simulation using the SB7b Tank 40 sample. The simulation included a Sludge Receipt and Adjustment Tank (SRAT) cycle, where acid was added to the sludge to destroy nitrite and reduce mercury, and a Slurry Mix Evaporator (SME) cycle, where glass frit was added to the sludge in preparation for vitrification. The SME cycle also included replication of five canister decontamination additions and concentrations. Processing parameters were based on work with a nonradioactive simulant.

- Vitrification of a portion of the SME product and characterization and durability testing (as measured by the Product Consistency Test (PCT)) of the resulting glass.

- Rheology measurements of the SRAT receipt, SRAT product, and SME product.

This program was controlled by a Task Technical and Quality Assurance Plan (TTQAP) ${ }^{2}$, and analyses were guided by an Analytical Study Plan ${ }^{3}$. This work is Technical Baseline Research and Development (R\&D) for the DWPF.

It should be noted that much of the data in this document has been published in interoffice memoranda. The intent of this technical report is bring all of the SB7b related data together in a single permanent record and to discuss the overall aspects of SB7b processing. 


\subsection{Sample Preparation and Characterization}

SRNL utilized portions of three tank samples for SB7b qualification:

- Tank 7: Tank Farm sample ID FTF-07-11-3. This sample was received specifically for SB7b qualification activities. The sample contained transfers from Tanks 4 and 12 and a heel from oxalic acid cleaning of Tanks 5 and 6.

- Tank 51: Tank Farm sample ID HTF-11-51-28. This sample was received as the Tank 51 SB7a confirmation sample. The sample underwent additional washing and decanting before blending with the SB7b sample to more closely match the heel in Tank 51 after the SB7a transfer.

- Tank 40: Tank Farm sample ID HTF-11-40-66. This sample was received for SB7a Waste Acceptance Product Specification characterization.

SB7b samples were then produced from the above samples. This section describes characterization methods and results for the above as-received samples. Descriptions of the SRNL-made SB7b samples along with characterization results are also included.

\subsection{Description of Analytical Methods}

Density measurements were conducted at a temperature of $\sim 25{ }^{\circ} \mathrm{C}$. This temperature was governed by the Shielded Cells conditions at the time of the measurements. Densities were measured using weight-calibrated balances and $8-9 \mathrm{~mL}$ volume-calibrated plastic test tubes. ${ }^{4}$ Four individual slurry aliquots and four individual supernatant aliquots were utilized in the measurements. Supernatant was generated by passing slurry through a $0.45 \mu \mathrm{m}$ filtration membrane.

Total solids and dissolved solids determinations were performed by driving water from slurry and supernatant aliquots (respectively) at a nominal temperature of $\sim 115^{\circ} \mathrm{C}$. $^{4}$ Four individual slurry aliquots and four individual supernatant aliquots were utilized in the measurements. The mass of each aliquot was $\sim 3.0 \mathrm{~g}$. Insoluble and soluble solids concentrations were calculated based on the total solids and dissolved solids measurements. Calcined solids were then generated by heating the dried slurry aliquots (from the total solids measurements) to a temperature of $\sim 1100^{\circ} \mathrm{C}$.

In preparation for elemental analyses, sludge solids aliquots were digested by both aqua regia (AR) and sodium peroxide fusion (PF) methods. Four individual sludge aliquots were utilized in each method. The total solids mass of each aliquot was $\sim 0.25 \mathrm{~g}$, and the volume of each final digest solution was $100 \mathrm{~mL}$. Inductively coupled plasma atomic emission spectroscopy (ICPAES) measurements were performed on both the AR and PF digest solutions. Cold vapor atomic absorption (CVAA) and inductively coupled plasma mass spectroscopy (ICP-MS) measurements were performed only on the AR digest solutions. ICP-AES measurements of AR digest solutions were used to quantify a majority of the elements. ICP-AES measurements of PF digest solutions were used to quantify $\mathrm{Al}$ and Si. CVAA measurements were used to quantify As, $\mathrm{Hg}$, and Se. The concentration of Nd was calculated from ICP-MS measurements by the sum of masses 143 to 146, 148, and 150. Noble metals ( $\mathrm{Ag}, \mathrm{Rh}, \mathrm{Ru}$, and $\mathrm{Pd}$ ) were calculated from ICP-MS analysis using the methodology given in Reference ${ }^{5}$.

All supernatant analyses were performed on dilutions of nominally $1.5 \mathrm{~g}$ of supernatant diluted to $50 \mathrm{~mL}$ of de-ionized water. Four diluted supernatant aliquots were analyzed by each measurement technique. ICP-AES was used to quantify sodium, aluminum (assumed to be aluminate), and sulfur (assumed to be sulfate); ion chromatography was used to quantify nitrite, 
nitrate, and oxalate; base titration was used to quantify free hydroxide; and total inorganic carbon analysis was used to quantify carbonate.

The analytical methods for radionuclide analyses are presented in Table 2-1. For each radionuclide, this table identifies: a) whether the analysis was performed on supernatant or on slurry; b) the type of slurry digestion that was performed (if applicable); c) whether a chemical separation was performed prior to measurements; d) the measurement technique utilized; and e) any other pertinent information applicable to the result.

Table 2-1. Summary of Analytical Methods

\begin{tabular}{|c|c|c|c|c|c|c|c|c|}
\hline Radionuclides & 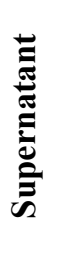 & 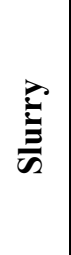 & 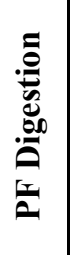 & 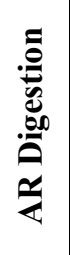 & 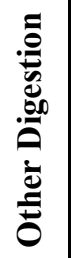 & 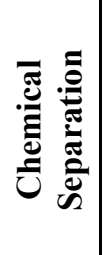 & 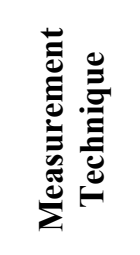 & Other Information \\
\hline $\mathrm{H}-3$ & $\mathbf{X}$ & & & & & $\mathbf{X}$ & LSC & \\
\hline $\mathrm{C}-14$ & & & & & & & $\mathrm{n} / \mathrm{a}$ & SRR projection (Ref. 6) \\
\hline $\begin{array}{l}\text { Co-60, Ru-106, Sb-125, } \\
\text { Ce-144, Eu-154, } \\
\text { Eu-155, Am-241 }\end{array}$ & & $\mathbf{X}$ & $\mathbf{X}$ & & & $\mathbf{X}$ & $\gamma$-PHA & \\
\hline Sr-90 & & $\mathbf{X}$ & $\mathbf{X}$ & & & $\mathbf{X}$ & LSC & \\
\hline $\begin{array}{l}\text { Tc-99, Th-232, U-233, } \\
\text { U-234, U-235, U-236, } \\
\text { U-238, Np-237, Pu-239, } \\
\text { Pu-240, Pu-242 }\end{array}$ & & $\mathbf{X}$ & & $\mathbf{X}$ & & & ICP-MS & \\
\hline $\begin{array}{l}\text { Y-90, } \quad \text { Rh-106, } \quad \text { Te- } \\
\text { 125m, Ba-137m, Pr-144 }\end{array}$ & & & & & & & $\mathrm{n} / \mathrm{a}$ & $\begin{array}{l}\text { Calculated based on parent } \\
\text { activity }\end{array}$ \\
\hline $\mathrm{I}-129$ & & $\mathbf{X}$ & & & $\mathbf{X}$ & $\mathbf{X}$ & LEPS & \\
\hline Cs-134, Cs-137 & & $\mathbf{X}$ & $\mathbf{X}$ & & & & $\gamma$-PHA & \\
\hline Pm-147 & & $\mathbf{X}$ & $\mathbf{X}$ & & & $\mathbf{X}$ & LSC & \\
\hline $\mathrm{Pu}-238$ & & $\mathbf{X}$ & $\mathbf{X}$ & & & $\mathbf{X}$ & $\alpha$-PHA & \\
\hline $\mathrm{Pu}-241$ & & $\mathbf{X}$ & $\mathbf{X}$ & & & $\mathbf{X}$ & LSC & \\
\hline Am-242m, Cm-245 & & $\mathbf{X}$ & $\mathbf{X}$ & & $\mathbf{X}$ & $\mathbf{X}$ & ICP-MS & \\
\hline Am-243, Cm-244 & & $\mathbf{X}$ & $\mathbf{X}$ & & $\mathbf{X}$ & $\mathbf{X}$ & $\alpha$-PHA & \\
\hline Total alpha & & $\mathbf{X}$ & $\mathbf{X}$ & & & & LSC & \\
\hline Nonvolatile beta & & $\mathbf{X}$ & $\mathbf{X}$ & & & & LSC & \\
\hline Total gamma & & & & & & & $\mathrm{n} / \mathrm{a}$ & $\begin{array}{l}\text { Sum of primary detectable } \gamma \text { - } \\
\text { emitters (Ba-137m }+ \text { Am- } \\
241+\text { Eu-154 }+ \text { Eu-155 }+ \\
\text { Co-60) }\end{array}$ \\
\hline
\end{tabular}

Rheological properties of radioactive samples were determined using a Haake M5/RV30 rotoviscometer. The M5/RV30 is a Searle sensor system, where the bob rotates, and the cup is fixed. The torque and rotational speed of the bob are measured. Heating/cooling of the cup/sample/bob is through the holder for the cup. The shear stress is determined from the torque measurement and is independent of the rheological properties. Conditions that impact the 
measured torque are; slip (material does not properly adhere to the rotor or cup), phase separation (buildup of liquid layer on rotor), sedimentation (particles settling out of the shearing zone), homogeneous sample (void of air), lack of sample (gap not filled), excess sample (primarily impacts rheologically thin fluids), completely filling up the void below the bob (air buffer that is now filled with fluid) and Taylor vortices. The first five items yield lower stresses and the last three add additional stresses. The shear rate is geometrically determined using the equations of change (continuity and motion) and is that for a Newtonian fluid. This assumption also assumes that the flow field is fully developed and the flow is laminar. The shear rate can be calculated for non-Newtonian fluids using the measured data and fitting this data to the rheological model or corrected as recommended by Darby. ${ }^{7}$ In either case, for shear thinning non-Newtonian fluids typical of Savannah River Site (SRS) sludge wastes, the corrected shear rates are greater than their corresponding Newtonian shear rates, resulting in a mathematically thinner fluid. Correcting the flow curves will not be performed in this task, resulting in calculations giving a slightly more viscous fluid.

The bob typically used for measuring tank sludge or SRAT product is the MV I rotor. For SME product, the MV II rotor is used to perform the measurements, due to the larger frit particles that are present in the SME product. The MV II has a larger gap to accommodate the larger frit particles. The shape, dimensions, and geometric constants for the MV I and MV II rotors are provided in Table 2-2.

Prior to performing the measurements, the rotors and cups are inspected for physical damage. The torque/speed sensors and temperature bath are verified for functional operability using a bob/cup combination with a National Institute of Standards and Technology (NIST) traceable Newtonian oil standard, using the MV I rotor. The resulting flow curves are then fitted as a Newtonian fluid and this calculated viscosity must be within $\pm 10 \%$ of the reported NIST viscosity at a given temperature for the system to be considered functionally operable. An N10 oil standard was used to verify system operability prior to the sludge measurements.

The flow curves for the sludge were fitted to the down curves using the Bingham Plastic rheological model, Equation 1, where $\tau$ is the measured stress $(\mathrm{Pa}), \tau_{\mathrm{o}}$ is the Bingham Plastic yield stress $(\mathrm{Pa}), \mu_{\infty}$ is the plastic viscosity $(\mathrm{Pa} \cdot \mathrm{sec})$, and $\dot{\gamma}$ is the measured shear rate $\left(\mathrm{sec}^{-1}\right)$. During all these measurements, the sample remained in the cup for the $2^{\text {nd }}$ measurement, due to the limited sample availability.

\section{Equation 1}

$$
\tau=\tau_{o}+\mu_{\infty} \dot{\gamma}
$$


Table 2-2. MV I and MV II Rotor Specifications and Flow Curve Program

\begin{tabular}{|c|c|c|c|}
\hline Rotor Design & \multicolumn{3}{|c|}{ Dimensions and Flow Curve Program } \\
\hline & Rotor Type & MV I & MV II \\
\hline & Rotor radius $-\mathrm{R}_{\mathrm{i}}(\mathrm{mm})$ & 20.04 & 18.40 \\
\hline & Cup Radius - $\mathrm{R}_{\mathrm{a}}(\mathrm{mm})$ & 21.0 & 21.0 \\
\hline & Height of rotor $-\mathrm{L}(\mathrm{mm})$ & 60 & 60 \\
\hline & $\begin{array}{c}\text { Sample Volume }\left(\mathrm{cm}^{3}\right) \\
\text { minimum }\end{array}$ & 40 & 55 \\
\hline & A factor $(\mathrm{Pa} / \%$ torque $)$ & 3.22 & 3.76 \\
\hline & $\mathrm{M}$ factor $\left(\mathrm{s}^{-1} / \% \mathrm{RPM}\right)$ & 11.7 & 4.51 \\
\hline & Shear rate range $\left(\mathrm{s}^{-1}\right)$ & $0-600$ & $0-300$ \\
\hline & Ramp up time (min) & 5 & 5 \\
\hline & Hold time (min) & 1 & 1 \\
\hline & Ramp down time (min) & 5 & 5 \\
\hline
\end{tabular}

\subsection{As-Received Characterization Results}

Characterization results of the as-received Tank 7, Tank 40, and Tank 51 samples are given in the following tables. It should be noted that a large portion of these results has been published previously via memorandums. ${ }^{8-10}$ Density and solids distribution are given in Table 2-3; total solids composition is given in Table 2-5, and supernatant composition is given in Table 2-4.

Slight variation is expected in each tank composition due to differences in sludges; however, the results also illustrate changes in composition and properties as sludge is washed. Tank 7 was in the early stages of washing, Tank 51 was nearing the end of washing, and Tank 40 was a washed sludge being fed to DWPF. Supernatant density, wt \% dissolved solids, sodium in the total solids, and most ion concentrations decrease as sludge is washed. This is indeed the case when comparing the characterization results of these three tanks. It should be noted that the high nitrite in the Tank 51 sample is the result of nitrite addition for corrosion control.

Table 2-3. As-Received Tank 7, Tank 40, and Tank 51 Density and Wt \% Solids Results

\begin{tabular}{||l|c|c|c||}
\hline \hline Analysis & Tank 7 & Tank 51 & Tank 40 \\
\hline Slurry Density (g/mL) & 1.15 & 1.15 & 1.14 \\
\hline Supernatant Density (g/mL) & 1.13 & 1.08 & 1.05 \\
\hline Wt \% Total Solids & 18.5 & 19.3 & 17.2 \\
\hline Wt \% Dissolved Solids & 15.5 & 10.2 & 5.4 \\
\hline Wt \% Insoluble Solids & 3.6 & 10.1 & 12.5 \\
\hline Wt \% Soluble Solids & 14.9 & 9.2 & 4.7 \\
\hline Wt \% Calcined Solids & NM & 14.9 & 13.5 \\
\hline
\end{tabular}


Table 2-4. As-Received Supernatant Results (M)

\begin{tabular}{||l|c|c|c||}
\hline \hline Ion & Tank 7 & Tank 51 & Tank 40 \\
\hline $\mathrm{Na}^{+}$ & 3.3 & 1.8 & 1.0 \\
\hline $\mathrm{NO}_{2}{ }^{-}$ & 0.48 & 0.56 & 0.25 \\
\hline $\mathrm{NO}_{3}{ }^{-}$ & 0.43 & 0.27 & 0.098 \\
\hline${\mathrm{Free} \mathrm{OH}^{-}}^{-}$ & 1.0 & 0.34 & 0.20 \\
\hline $\mathrm{CO}_{3}{ }^{2-}$ & 0.28 & 0.12 & 0.10 \\
\hline $\mathrm{Al}(\mathrm{OH})_{4}{ }^{-}$ & 0.14 & 0.065 & 0.037 \\
\hline $\mathrm{C}_{2} \mathrm{O}_{4}{ }^{2-}$ & 0.019 & 0.046 & 0.050 \\
\hline $\mathrm{SO}_{4}{ }^{2-}$ & 0.15 & 0.045 & 0.019 \\
\hline
\end{tabular}


Table 2-5. As-Received Elemental Composition Results (wt \% in Total Solids)

\begin{tabular}{|c|c|c|c|}
\hline Element & Tank 7 & Tank 51 & Tank 40 \\
\hline $\mathrm{Ag}$ & $4.6 \mathrm{E}-03$ & NM & $1.8 \mathrm{E}-02$ \\
\hline $\mathrm{Al}$ & $2.9 \mathrm{E}+00$ & NM & $1.0 \mathrm{E}+01$ \\
\hline $\mathrm{B}$ & $8.0 \mathrm{E}-03$ & $3.6 \mathrm{E}-03$ & $<1.5 \mathrm{E}-02$ \\
\hline $\mathrm{Ba}$ & $4.2 \mathrm{E}-02$ & $6.8 \mathrm{E}-02$ & $1.0 \mathrm{E}-01$ \\
\hline $\mathrm{Be}$ & $1.2 \mathrm{E}-04$ & $1.9 \mathrm{E}-04$ & 3.4E-04 \\
\hline $\mathrm{Ca}$ & $2.0 \mathrm{E}-01$ & $4.3 \mathrm{E}-01$ & $7.2 \mathrm{E}-01$ \\
\hline $\mathrm{Cd}$ & $<1.0 \mathrm{E}-03$ & $1.4 \mathrm{E}-02$ & $3.6 \mathrm{E}-02$ \\
\hline $\mathrm{Ce}$ & $6.0 \mathrm{E}-02$ & $8.2 \mathrm{E}-02$ & $1.3 \mathrm{E}-01$ \\
\hline $\mathrm{Co}$ & $7.8 \mathrm{E}-03$ & $1.0 \mathrm{E}-02$ & $1.2 \mathrm{E}-02$ \\
\hline $\mathrm{Cr}$ & $5.9 \mathrm{E}-02$ & $4.9 \mathrm{E}-02$ & $4.6 \mathrm{E}-02$ \\
\hline $\mathrm{Cu}$ & $1.8 \mathrm{E}-02$ & $2.8 \mathrm{E}-02$ & $1.2 \mathrm{E}-01$ \\
\hline $\mathrm{Fe}$ & $5.9 \mathrm{E}+00$ & $9.6 \mathrm{E}+00$ & $1.4 \mathrm{E}+01$ \\
\hline $\mathrm{Gd}$ & $8.1 \mathrm{E}-03$ & $8.2 \mathrm{E}-02$ & $1.1 \mathrm{E}-01$ \\
\hline $\mathrm{Hg}$ & $1.8 \mathrm{E}-01$ & NM & $1.9 \mathrm{E}+00$ \\
\hline $\mathrm{K}$ & $1.3 \mathrm{E}-01$ & $8.8 \mathrm{E}-02$ & $5.4 \mathrm{E}-02$ \\
\hline $\mathrm{La}$ & $3.5 \mathrm{E}-02$ & $4.9 \mathrm{E}-02$ & $7.8 \mathrm{E}-02$ \\
\hline $\mathrm{Li}$ & $6.9 \mathrm{E}-03$ & $2.2 \mathrm{E}-02$ & $2.9 \mathrm{E}-02$ \\
\hline $\mathrm{Mg}$ & $4.6 \mathrm{E}-02$ & $2.2 \mathrm{E}-01$ & $3.7 \mathrm{E}-01$ \\
\hline $\mathrm{Mn}$ & $5.5 \mathrm{E}-01$ & $2.4 \mathrm{E}+00$ & $3.9 \mathrm{E}+00$ \\
\hline Mo & $1.0 \mathrm{E}-02$ & $6.5 \mathrm{E}-03$ & $<9.7 \mathrm{E}-03$ \\
\hline $\mathrm{Na}$ & $3.2 \mathrm{E}+01$ & $2.2 \mathrm{E}+01$ & $1.3 \mathrm{E}+01$ \\
\hline $\mathrm{Nd}$ & $1.2 \mathrm{E}-01$ & NM & $2.3 \mathrm{E}-01$ \\
\hline $\mathrm{Ni}$ & $1.7 \mathrm{E}+00$ & $1.8 \mathrm{E}+00$ & $2.4 \mathrm{E}+00$ \\
\hline $\mathrm{P}$ & 7.2E-02 & $3.8 \mathrm{E}-02$ & $6.0 \mathrm{E}-02$ \\
\hline $\mathrm{Pb}$ & $1.4 \mathrm{E}-02$ & $2.3 \mathrm{E}-02$ & $2.7 \mathrm{E}-02$ \\
\hline $\mathrm{Pd}$ & $1.5 \mathrm{E}-03$ & NM & $2.6 \mathrm{E}-03$ \\
\hline $\mathrm{Rh}$ & $9.6 \mathrm{E}-03$ & NM & $1.9 \mathrm{E}-02$ \\
\hline $\mathrm{Ru}$ & $4.6 \mathrm{E}-02$ & NM & $9.4 \mathrm{E}-02$ \\
\hline $\mathrm{S}$ & $1.9 \mathrm{E}+00$ & $6.0 \mathrm{E}-01$ & $2.3 \mathrm{E}-01$ \\
\hline $\mathrm{Sb}$ & $8.6 \mathrm{E}-03$ & $1.7 \mathrm{E}-02$ & $<2.0 \mathrm{E}-02$ \\
\hline $\mathrm{Si}$ & $2.4 \mathrm{E}-01$ & ND & $1.2 \mathrm{E}+00$ \\
\hline $\mathrm{Sn}$ & $<3.4 \mathrm{E}-03$ & $<3.4 \mathrm{E}-03$ & $<8.9 \mathrm{E}-03$ \\
\hline $\mathrm{Sr}$ & $1.7 \mathrm{E}-02$ & $3.2 \mathrm{E}-02$ & $4.8 \mathrm{E}-02$ \\
\hline $\mathrm{Th}$ & $1.3 \mathrm{E}-01$ & $8.2 \mathrm{E}-01$ & $1.5 \mathrm{E}+00$ \\
\hline $\mathrm{Ti}$ & $5.5 \mathrm{E}-03$ & $1.2 \mathrm{E}-02$ & $1.8 \mathrm{E}-02$ \\
\hline $\mathrm{U}$ & $1.9 \mathrm{E}+00$ & $3.7 \mathrm{E}+00$ & $4.7 \mathrm{E}+00$ \\
\hline V & $<4.2 \mathrm{E}-04$ & $<4.1 \mathrm{E}-04$ & $<7.4 \mathrm{E}-04$ \\
\hline $\mathrm{Zn}$ & $2.0 \mathrm{E}-02$ & $3.5 \mathrm{E}-02$ & $4.3 \mathrm{E}-02$ \\
\hline $\mathrm{Zr}$ & $1.0 \mathrm{E}-01$ & $1.5 \mathrm{E}-01$ & $1.4 \mathrm{E}-01$ \\
\hline
\end{tabular}

2.3 Preparation and Characterization of SRNL-Prepared Sludge Batch 7b Qualification Samples Following the receipt and characterization of the Tank 51 SB7a confirmation sample (HTF-5111-28, see Section 2.2 above), the sample was washed by SRNL per Tank Farm plans of April 27, 2011. Tank Farm washing plans included a Wash/Decant I, J, and K prior to transfer of Tank 51 to Tank 40. SRNL's washes and decants were proportional to the Tank Farm volumes. The washed material was then characterized with respect to densities, solids distribution, and primary supernatant ions (no dissolutions for elemental analyses were performed). Results are presented in Table 2-6. Note that these results have been published previously. ${ }^{11}$ 
Table 2-6. Analytical Results of the SRNL-Washed Tank 51 SB7a Confirmation Sample

\begin{tabular}{|c|c|}
\hline Analysis & Result \\
\hline Slurry Density $(\mathrm{g} / \mathrm{mL})$ & 1.12 \\
\hline Supernatant Density $(\mathrm{g} / \mathrm{mL})$ & 1.05 \\
\hline Wt \% Total Solids (slurry basis) & 18.4 \\
\hline Wt \% Dissolved Solids (supernatant basis) & 6.5 \\
\hline Wt \% Insoluble Solids (slurry basis) & 12.7 \\
\hline $\mathrm{Wt} \%$ Soluble Solids (slurry basis) & 5.7 \\
\hline Wt \% Calcined Solids & 14.3 \\
\hline $\mathrm{Na}^{+}(\mathrm{mol} / \mathrm{L}$ supernatant $)$ & 1.1 \\
\hline $\mathrm{Al}(\mathrm{OH})_{4}^{-}(\mathrm{mol} / \mathrm{L}$ supernatant $)$ & 0.033 \\
\hline $\mathrm{SO}_{4}{ }^{2-}(\mathrm{mol} / \mathrm{L}$ supernatant $)$ & 0.023 \\
\hline $\mathrm{CO}_{3}^{2-}(\mathrm{mol} / \mathrm{L} \text { supernatant })^{\dagger}$ & 0.055 \\
\hline $\mathrm{NO}_{2}^{-}(\mathrm{mol} / \mathrm{L}$ supernatant $)$ & 0.22 \\
\hline $\mathrm{NO}_{3}^{-}(\mathrm{mol} / \mathrm{L}$ supernatant $)$ & 0.11 \\
\hline $\mathrm{C}_{2} \mathrm{O}_{4}{ }^{2-}(\mathrm{mol} / \mathrm{L}$ supernatant $)$ & 0.090 \\
\hline Free $\mathrm{OH}^{-}$(mol/L supernatant) & 0.25 \\
\hline
\end{tabular}

SRNL then prepared two SB7b samples based on Tank Farm projections: a Tank 51 SB7b sample, representing projected Tank 51 conditions at the conclusion of SB7b preparations, and a Tank 40 SB7b sample, representing Tank 40 following the transfer of Tank 51 SB7b to Tank 40.

The preparation of the Tank $51 \mathrm{SB} 7 \mathrm{~b}$ sample is outlined below. Once again, significant time constraints and the fact that information on washing and settling times was not required resulted in a slightly different preparation and washing strategy for this sludge batch. Rather than performing several washes/decants to simulate Tank Farm washing, SRNL added a sodium solution to obtain the target supernatant composition with only one wash. The preparation of the Tank 51 SB7b sample is outlined below.

- Began with 2,850 mL of as-received Tank 7 slurry.

- Decanted 2,270 mL of Tank 7 supernatant.

- Added $350 \mathrm{~mL}$ of the SRNL-washed Tank 51 SB7a slurry.

- Added $10 \mathrm{~mL}$ of H Canyon Pu solution.

- Added 1,500 $\mathrm{mL}$ of wash water. The wash water had a composition of $0.44 \mathrm{M} \mathrm{Na}^{+}, 0.14$ $\mathrm{M} \mathrm{NO}_{2}^{-}, 0.018 \mathrm{M} \mathrm{NO}_{3}^{-}, 0.30 \mathrm{M} \mathrm{OH}^{-}$, and $0.0068 \mathrm{SO}_{4}{ }^{2-}$.

- Decanted 1,200 $\mathrm{mL}$ of supernatant.

The Tank 40 SB7b sample was produced by combining $1,070 \mathrm{~mL}$ of Tank 40 slurry with $440 \mathrm{~mL}$ of the SRNL-produced Tank 51 SB7b slurry. Characterization results of these two samples are presented in Table 2-7, Table 2-8, and Table 2-9. A majority of these results has been previously published. ${ }^{12}$ 
SRNL-STI-2011-00548

Revision 0

Table 2-7. Density and Wt \% Solids Results

\begin{tabular}{||c|c|c|}
\hline Property & Tank 51 SB7b & Tank 40 SB7b \\
\hline $\begin{array}{c}\text { Slurry Density } \\
(\mathrm{g} / \mathrm{mL})\end{array}$ & 1.14 & 1.12 \\
\hline $\begin{array}{c}\text { Supernatant Density } \\
(\mathrm{g} / \mathrm{mL})\end{array}$ & 1.05 & 1.06 \\
\hline $\begin{array}{l}\mathrm{W} \% \text { Total Solids } \\
\text { (Slurry Basis) }\end{array}$ & 17.9 & 16.1 \\
\hline $\begin{array}{c}\text { Wt\% Calcined Solids (Slurry } \\
\text { Basis) }\end{array}$ & 14.4 & 6.1 \\
\hline $\begin{array}{c}\mathrm{Wt} \% \text { Dissolved Solids } \\
\text { (Supernatant Basis) }\end{array}$ & 6.4 & 10.6 \\
\hline $\begin{array}{l}\text { Wt\% Insoluble Solids (Slurry } \\
\text { Basis) }\end{array}$ & 12.2 & 5.5 \\
\hline $\begin{array}{c}\text { Wt\% Soluble Solids } \\
\text { (Slurry Basis) }\end{array}$ & 5.7 & \\
\hline
\end{tabular}


Table 2-8. Elemental Composition Results (wt \% in total solids)

\begin{tabular}{|l|c|c||}
\hline \multicolumn{1}{|c|}{ Element } & $\begin{array}{c}\text { Tank 51 } \\
\text { SB7b }\end{array}$ & Tank 40 SB7b \\
\hline $\mathrm{Ag}$ & $1.1 \mathrm{E}-02$ & $1.1 \mathrm{E}-02$ \\
\hline $\mathrm{Al}$ & $6.7 \mathrm{E}+00$ & $8.8 \mathrm{E}+00$ \\
\hline $\mathrm{As}$ & $<1.1 \mathrm{E}-03$ & NM \\
\hline $\mathrm{B}$ & $<7 \mathrm{E}-03$ & $<8 \mathrm{E}-03$ \\
\hline $\mathrm{Ba}$ & $1.3 \mathrm{E}-01$ & $1.0 \mathrm{E}-01$ \\
\hline $\mathrm{Be}$ & $2.7 \mathrm{E}-04$ & $4.4 \mathrm{E}-04$ \\
\hline $\mathrm{Ca}$ & $6.6 \mathrm{E}-01$ & $6.4 \mathrm{E}-01$ \\
\hline $\mathrm{Cd}$ & $2.3 \mathrm{E}-02$ & $3.0 \mathrm{E}-02$ \\
\hline $\mathrm{Ce}$ & $1.9 \mathrm{E}-01$ & $2.4 \mathrm{E}-01$ \\
\hline $\mathrm{Co}$ & $1.7 \mathrm{E}-02$ & $1.3 \mathrm{E}-02$ \\
\hline $\mathrm{Cr}$ & $4.4 \mathrm{E}-02$ & $4.3 \mathrm{E}-02$ \\
\hline $\mathrm{Cu}$ & $7.8 \mathrm{E}-02$ & $8.0 \mathrm{E}-02$ \\
\hline $\mathrm{Fe}$ & $1.8 \mathrm{E}+01$ & $1.4 \mathrm{E}+01$ \\
\hline $\mathrm{Gd}$ & $1.1 \mathrm{E}-01$ & $1.0 \mathrm{E}-01$ \\
\hline $\mathrm{Hg}$ & $7.1 \mathrm{E}-01$ & $1.3 \mathrm{E}+00$ \\
\hline $\mathrm{K}$ & $6.1 \mathrm{E}-02$ & $<3 \mathrm{E}-02$ \\
\hline $\mathrm{La}$ & $1.1 \mathrm{E}-01$ & $8.3 \mathrm{E}-02$ \\
\hline $\mathrm{Li}$ & $2.6 \mathrm{E}-02$ & $2.7 \mathrm{E}-02$ \\
\hline $\mathrm{Mg}$ & $2.0 \mathrm{E}-01$ & $2.9 \mathrm{E}-01$ \\
\hline $\mathrm{Mn}$ & $2.4 \mathrm{E}+00$ & $3.0 \mathrm{E}+00$ \\
\hline $\mathrm{Mo}$ & $<5 \mathrm{E}-03$ & $4.9 \mathrm{E}-03$ \\
\hline $\mathrm{Na}$ & $1.5 \mathrm{E}+01$ & $1.4 \mathrm{E}+01$ \\
\hline $\mathrm{Nd}$ & $3.3 \mathrm{E}-01$ & $2.5 \mathrm{E}-01$ \\
\hline $\mathrm{Ni}$ & $4.7 \mathrm{E}+00$ & $2.9 \mathrm{E}+00$ \\
\hline $\mathrm{P}$ & $<1 \mathrm{E}-01$ & $1.0 \mathrm{E}-01$ \\
\hline $\mathrm{Pb}$ & $3.9 \mathrm{E}-02$ & $<5 \mathrm{E}-02$ \\
\hline $\mathrm{Pd}$ & $2.0 \mathrm{E}-03$ & $2.4 \mathrm{E}-03$ \\
\hline $\mathrm{Rh}$ & $2.7 \mathrm{E}-02$ & $2.1 \mathrm{E}-02$ \\
\hline $\mathrm{Ru}$ & $1.3 \mathrm{E}-01$ & $1.0 \mathrm{E}-01$ \\
\hline $\mathrm{S}$ & $6.7 \mathrm{E}-01$ & $4.6 \mathrm{E}-01$ \\
\hline $\mathrm{Sb}$ & $3.6 \mathrm{E}-02$ & $2.2 \mathrm{E}-02$ \\
\hline $\mathrm{Se}$ & $<2 \mathrm{E}-03$ & NM \\
\hline $\mathrm{Si}$ & $1.0 \mathrm{E}+00$ & $1.1 \mathrm{E}+00$ \\
\hline $\mathrm{Sn}$ & $7.2 \mathrm{E}-03$ & $<4 \mathrm{E}-02$ \\
\hline $\mathrm{Sr}$ & $5.5 \mathrm{E}-02$ & $4.5 \mathrm{E}-02$ \\
\hline $\mathrm{Th}$ & $6.4 \mathrm{E}-01$ & $1.0 \mathrm{E}+00$ \\
\hline $\mathrm{Ti}$ & $1.8 \mathrm{E}-02$ & $1.7 \mathrm{E}-02$ \\
\hline $\mathrm{U}$ & $6.0 \mathrm{E}+00$ & $4.8 \mathrm{E}+00$ \\
\hline $\mathrm{V}$ & $<3 \mathrm{E}-04$ & $<3 \mathrm{E}-04$ \\
\hline $\mathrm{Zn}$ & $3.7 \mathrm{E}-02$ & $4.8 \mathrm{E}-02$ \\
\hline $\mathrm{Zr}$ & $1.6 \mathrm{E}-01$ & $2.5 \mathrm{E}-01$ \\
\hline & & \\
\hline & & \\
\hline
\end{tabular}


Table 2-9. Tank 51 SB7b and Tank 40 SB7b Supernatant Results (M)

\begin{tabular}{|l|c|c|}
\hline Ion & $\begin{array}{c}\text { Tank 51 } \\
\text { SB7b }\end{array}$ & Tank 40 SB7b \\
\hline $\mathrm{Na}^{+}$ & 1.0 & 1.0 \\
\hline $\mathrm{NO}_{2}{ }^{-}$ & 0.23 & 0.25 \\
\hline $\mathrm{NO}_{3}{ }^{-}$ & 0.11 & 0.11 \\
\hline Free $\mathrm{OH}^{-}$ & 0.34 & 0.25 \\
\hline $\mathrm{CO}_{3}{ }^{2-}$ & $0.066^{\mathrm{b}}$ & 0.087 \\
\hline $\mathrm{Al}^{(\mathrm{OH})_{4}{ }^{-}}$ & 0.034 & 0.036 \\
\hline $\mathrm{C}_{2} \mathrm{O}_{4}{ }^{2-}$ & 0.018 & 0.043 \\
\hline $\mathrm{SO}_{4}{ }^{2-}(\mathrm{ICP}-\mathrm{AES})$ & $\mathrm{ND}^{\mathrm{a}}$ & 0.027 \\
\hline $\mathrm{F}^{-}$ & $<0.01$ & $<0.01$ \\
\hline $\mathrm{HCO}_{2}{ }^{-}$ & $<0.005$ & $<0.004$ \\
\hline $\mathrm{Cl}$ & $<0.006$ & $<0.006$ \\
\hline Phosphate & $<0.002$ & $<0.002$ \\
\hline Sulfate (IC) & 0.029 & 0.022 \\
\hline
\end{tabular}

${ }^{a} \mathrm{ND}=$ Not Determined. The Quality Control check of sulfur for this set of samples was outside of specifications. Samples were not rerun since an estimate of sulfur can be obtained from IC analysis, and total sulfur was determined from a slurry digestion (see Table 2-8).

${ }^{\mathrm{b}}$ Carbonate is calculated from a total inorganic carbon result, assuming all inorganic carbon is carbonate.

\subsection{Radionuclides in the Tank 51 SB7b Sample}

Radionuclide concentrations in the SB7b Tank 51 sample are given below in Table 2-10. These results have been published in Reference 13. These are radionuclides necessary for the transfer of Tank 51 to Tank 40, as requested in the TTR. ${ }^{1}$

Most of the radioactivity is due to beta-emitter Sr-90 and its short-lived beta-emitting daughter Y-90. Summing their concentrations with the next most dominant beta-emitter, Cs-137, gives a total beta activity concentration of 3.5E-2 Curies per gram of total solids. This value is about $10 \%$ lower than nonvolatile beta concentration determined via gross analysis (4.0E-2 Curies per gram of total solids). Given that the analytical uncertainties of the radiometric methods are typically $10-20 \%$, the agreement between the two sets of results is considered very good.

The concentration of alpha activity is two orders of magnitude lower than the beta activity. Specifically, the sum of alpha activity due to the dominant alpha-emitters (Pu-238, $\mathrm{Pu}-239, \mathrm{Pu}-$ 240, Am-241, and Cm-244) is 1.7E-4 Curies per gram of total solids. This value is consistent with the total alpha concentration determined via gross analysis $(<2.4 \mathrm{E}-4$ Curies per gram of total solids).

The primary photon-emitter is Ba- $137 \mathrm{~m}$ (the short-lived daughter of Cs-137), with a concentration of 5.6E-4 Curies per gram of total solids. The next most dominant photon-emitters are $\mathrm{Eu}-154$, Eu-155, and Co-60, with concentrations of 1.7E-5, 5.7E-6, and 4.5E-6 Curies per gram of total solids, respectively.

The RSD values provide an indication of measurement precision, which is helpful for identifying unusual analytical fluctuations. Although none of the RSD values are considered unacceptably large, it should be noted that those for Pu-240, Cm-244, and Cm-245 are on the order of $30-40 \%$, while those for all other analytes are less than $15 \%$. What this suggests is that the uncertainties for the Pu-240, Cm-244, and Cm-245 results may be higher than those for the other results. 
Table 2-10. Mean Concentrations of Radionuclides in the SB7b Qualification Sample

\begin{tabular}{|c|c|c|c|c|}
\hline Radionuclide & Ci per gram of total solids & Ci per gallon of slurry & wt\% of total solids & \%RSD \\
\hline $\mathrm{H}-3$ & NA & $<3.9 \mathrm{E}-05$ & NA & $\mathrm{NA}$ \\
\hline $\mathrm{C}-14$ & $1.4 \mathrm{E}-09^{\mathrm{a}}$ & $9.5 \mathrm{E}-07^{\mathrm{a}}$ & $3.2 \mathrm{E}-08$ & NA \\
\hline Co-60 & $4.5 \mathrm{E}-06$ & $3.5 \mathrm{E}-03$ & $4.0 \mathrm{E}-07$ & 1.3 \\
\hline Sr-90 & $1.7 \mathrm{E}-02$ & $1.3 \mathrm{E}+01$ & $1.3 \mathrm{E}-02$ & 1.6 \\
\hline Y-90 & $1.7 \mathrm{E}-02$ & $1.3 \mathrm{E}+01$ & $3.2 \mathrm{E}-06$ & NA \\
\hline Tc-99 & $9.2 \mathrm{E}-08$ & $7.1 \mathrm{E}-05$ & 5.4E-04 & $14^{\mathrm{b}}$ \\
\hline Ru-106 & $<6.4 \mathrm{E}-07$ & $<5.0 \mathrm{E}-04$ & $<1.9 \mathrm{E}-08$ & NA \\
\hline Rh-106 & $<6.4 \mathrm{E}-07$ & $<5.0 \mathrm{E}-04$ & $<1.8 \mathrm{E}-14$ & $\overline{\mathrm{NA}}$ \\
\hline Sb-125 & $<1.8 \mathrm{E}-07$ & $<1.4 \mathrm{E}-04$ & $<1.8 \mathrm{E}-08$ & NA \\
\hline $\mathrm{Te}-125 \mathrm{~m}$ & $<1.8 \mathrm{E}-07$ & $<1.4 \mathrm{E}-04$ & $<1.0 \mathrm{E}-09$ & NA \\
\hline $\mathrm{I}-129$ & $8.1 \mathrm{E}-10$ & $6.3 \mathrm{E}-07$ & $4.6 \mathrm{E}-04$ & 8.6 \\
\hline Cs-134 & $<3.5 \mathrm{E}-06$ & $<2.7 \mathrm{E}-03$ & $<2.7 \mathrm{E}-07$ & $\mathrm{NA}$ \\
\hline Cs-137 & $5.9 \mathrm{E}-04$ & 4.6E-01 & $6.8 \mathrm{E}-04$ & 2.2 \\
\hline Ba-137m & $5.6 \mathrm{E}-04$ & $4.3 \mathrm{E}-01$ & $1.0 \mathrm{E}-10$ & $\mathrm{NA}$ \\
\hline $\mathrm{Ce}-144$ & $<9.9 \mathrm{E}-07$ & $<7.7 \mathrm{E}-04$ & $<3.1 \mathrm{E}-08$ & $\mathrm{NA}$ \\
\hline Pr-144 & $<9.9 \mathrm{E}-07$ & $<7.7 \mathrm{E}-04$ & $<1.3 \mathrm{E}-12$ & NA \\
\hline Pm-147 & $<2.3 \mathrm{E}-04$ & $<1.8 \mathrm{E}-01$ & $<2.5 \mathrm{E}-05$ & $\overline{\mathrm{NA}}$ \\
\hline Eu-154 & $1.7 \mathrm{E}-05$ & $1.3 \mathrm{E}-02$ & $6.2 \mathrm{E}-06$ & 1.7 \\
\hline Eu-155 & $5.7 \mathrm{E}-06$ & $4.4 \mathrm{E}-03$ & $1.2 \mathrm{E}-06$ & 10 \\
\hline Th-232 & $5.4 \mathrm{E}-10$ & $4.2 \mathrm{E}-07$ & $5.0 \mathrm{E}-01$ & 4.5 \\
\hline $\mathrm{U}-233$ & $<9.2 \mathrm{E}-08$ & $<7.1 \mathrm{E}-05$ & $<9.5 \mathrm{E}-04$ & NA \\
\hline U-234 & $3.9 \mathrm{E}-08$ & $3.0 \mathrm{E}-05$ & $6.2 \mathrm{E}-04$ & $13^{\mathrm{c}}$ \\
\hline U-235 & $6.2 \mathrm{E}-10$ & $4.8 \mathrm{E}-07$ & $2.8 \mathrm{E}-02$ & 5.5 \\
\hline U-236 & 7.4E-10 & $5.7 \mathrm{E}-07$ & $1.1 \mathrm{E}-03$ & 4.8 \\
\hline $\mathrm{U}-238$ & $1.9 \mathrm{E}-08$ & $1.4 \mathrm{E}-05$ & $5.5 \mathrm{E}+00$ & 2.7 \\
\hline $\mathrm{Np}-237$ & $2.2 \mathrm{E}-08$ & $1.7 \mathrm{E}-05$ & $3.1 \mathrm{E}-03$ & 6.4 \\
\hline $\mathrm{Pu}-238$ & $6.5 \mathrm{E}-05$ & $5.0 \mathrm{E}-02$ & $3.8 \mathrm{E}-04$ & 3.5 \\
\hline $\mathrm{Pu}-239$ & $8.5 \mathrm{E}-06$ & $6.6 \mathrm{E}-03$ & $1.4 \mathrm{E}-02$ & 3.3 \\
\hline $\mathrm{Pu}-240$ & $3.2 \mathrm{E}-06$ & $2.4 \mathrm{E}-03$ & $1.4 \mathrm{E}-03$ & $27^{\mathrm{d}}$ \\
\hline $\mathrm{Pu}-241$ & $\sim 2.5 \mathrm{E}-05$ & $\sim 2.0 \mathrm{E}-02$ & $\sim 2.5 \mathrm{E}-05$ & $\mathrm{NA}^{\mathrm{e}}$ \\
\hline $\mathrm{Pu}-242$ & $<2.9 \mathrm{E}-08$ & $<2.2 \mathrm{E}-05$ & $<7.6 \mathrm{E}-04$ & NA \\
\hline Am-241 & $6.0 \mathrm{E}-05$ & $4.6 \mathrm{E}-02$ & $1.7 \mathrm{E}-03$ & 4.2 \\
\hline Am-242m & $3.9 \mathrm{E}-08$ & $3.0 \mathrm{E}-05$ & $4.0 \mathrm{E}-07$ & $12^{f}$ \\
\hline Am-243 & 7.4E-07 & $5.7 \mathrm{E}-04$ & $3.7 \mathrm{E}-04$ & 7.9 \\
\hline $\mathrm{Cm}-244$ & $3.1 \mathrm{E}-05$ & $2.4 \mathrm{E}-02$ & $3.8 \mathrm{E}-05$ & 33 \\
\hline $\mathrm{Cm}-245$ & $4.7 \mathrm{E}-09$ & $3.6 \mathrm{E}-06$ & $2.7 \mathrm{E}-06$ & 36 \\
\hline Total alpha & $<2.6 \mathrm{E}-04$ & $<2.0 \mathrm{E}-01$ & NA & NA \\
\hline $\begin{array}{l}\text { Nonvolatile } \\
\text { beta }\end{array}$ & $4.0 \mathrm{E}-02$ & $3.1 \mathrm{E}+01$ & NA & 1.7 \\
\hline Total gamma & $6.5 \mathrm{E}-04$ & $5.0 \mathrm{E}-01$ & NA & NA \\
\hline
\end{tabular}

${ }^{\mathrm{a}} \mathrm{The} \mathrm{Ci} / \mathrm{g}$ and $\mathrm{Ci} / \mathrm{gal}$ values for $\mathrm{C}-14$ were taken from Reference 6 . (The $\mathrm{wt} \%$ value for $\mathrm{C}-14$ was calculated from the $\mathrm{Ci} / \mathrm{g}$ value). ${ }^{b}$ One of the four replicate analysis results for Tc-99 was identified as having elevated uncertainty. ${ }^{c}$ Three of the four replicate analysis results for U-234 were identified as having elevated uncertainties. ${ }^{\mathrm{d}}$ Two of the four replicate analysis results for Pu-240 were identified as having elevated uncertainties. ${ }^{\mathrm{e}}$ The Pu-241 concentration was the same order of magnitude as the minimum detection limit (MDL), and only one of the four replicate analyses yielded a result exceeding the MDL. This particular result was identified in the table with an approximation sign (see " " symbol), since the value was based on a single analysis and the uncertainty may have been higher than normal, due to the result being close to the MDL. Because the reported value is based on a single analytical result, an RSD is not applicable. ${ }^{\mathrm{f}}$ Only three of the four replicate analyses for Am-242m yielded results exceeding the MDL. The values in the table were based on these three results. 
Table 2-11. Fissile Isotope Analytical Results for Each of the Four Replicates (Reported to Three Digits for Purposes of Comparison)

\begin{tabular}{|l|c|c|c|c||}
\hline \multirow{2}{*}{ Isotope } & \multicolumn{4}{|c||}{ Measured Concentration, wt\% of total solids } \\
\cline { 2 - 5 } & $\mathbf{\# 1}$ & $\mathbf{\# 2}$ & $\mathbf{\# 3}$ & $\mathbf{\# 4}$ \\
\hline $\mathrm{U}-233$ & $<9.54 \mathrm{E}-04$ & $<9.47 \mathrm{E}-04$ & $<9.47 \mathrm{E}-04$ & $<9.51 \mathrm{E}-04$ \\
\hline $\mathrm{U}-235$ & $2.90 \mathrm{E}-02$ & $2.65 \mathrm{E}-02$ & $3.02 \mathrm{E}-02$ & $2.82 \mathrm{E}-02$ \\
\hline $\mathrm{Pu}-239$ & $1.35 \mathrm{E}-02$ & $1.32 \mathrm{E}-02$ & $1.40 \mathrm{E}-02$ & $1.42 \mathrm{E}-02$ \\
\hline $\mathrm{Pu}-241$ & $<3.30 \mathrm{E}-05$ & $<1.87 \mathrm{E}-05$ & $<4.30 \mathrm{E}-05$ & $2.47 \mathrm{E}-05$ \\
\hline
\end{tabular}

\subsection{Chemical Process Cell Simulations}

This section describes the DWPF CPC simulations using the SRNL-prepared Tank 40 SB7b sample, also designated as the SRAT receipt sample. Simulations were performed in the SRNL Shielded Cells. These simulations were designated as SC-12. The first subsection provides an overview of the simulations and an equipment description. The remaining subsections contain results and discussions of the SRAT and SME cycles.

\section{1 $\mathrm{CPC}$ Simulations Overview and Equipment Description}

DWPF simulations (SRAT and SME cycles) using the SRNL-prepared Tank 40 SB7b qualification sample were conducted following procedures in the Environmental and Chemical Process Technology Research Programs Section procedure manual. ${ }^{4}$ A summary of each cycle is given in Table 3-1.

Table 3-1. Planned SB7b Qualification CPC Processing

\begin{tabular}{|c|c|}
\hline SRAT Cycle & SME Cycle \\
\hline 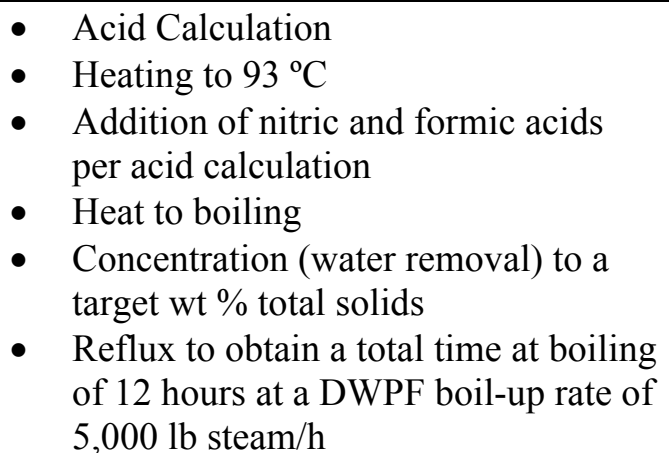 & $\begin{array}{l}\text { - Addition and removal of water to } \\
\text { simulate addition and removal of } \\
\text { water from the decontamination of } 5 \\
\text { glass canisters } \\
\text { Addition of frit and dilute formic acid } \\
\text { in two batches to target } 36 \% \text { waste } \\
\text { loading } \\
\text { Concentration (water removal) to } \\
\text { target } 45-50 \mathrm{wt} \% \text { total solids. }\end{array}$ \\
\hline
\end{tabular}

The SB7b qualification CPC processing was performed using a vessel designed to process one liter of sludge. This vessel is of the same design as used in the last three qualification runs. The SRAT rig was assembled and tested in the SRNL Shielded Cells Mockup area and placed into the Shielded Cells fully assembled. The intent of the equipment is to functionally replicate the DWPF processing vessels. The glass kettle is used to replicate both the SRAT and the SME, and it is connected to the SRAT Condenser and the Mercury Water Wash Tank (MWWT). Because the DWPF Formic Acid Vent Condenser (FAVC) does not directly impact SRAT and SME chemistry, it is not included in SRNL Shielded Cells CPC processing. Instead, a simple "cold finger" condenser is used to cool off-gas to approximately $20^{\circ} \mathrm{C}$ below ambient to remove excess 
water before the gas reaches the micro gas chromatograph (GC) for characterization. The Slurry Mix Evaporator Condensate Tank (SMECT) is represented by a sampling bottle that is used to remove condensate through the MWWT. For the purposes of this paper, the condensers and wash tank are referred to as the off-gas components. A sketch of the experimental setup is given as Figure 3-1.

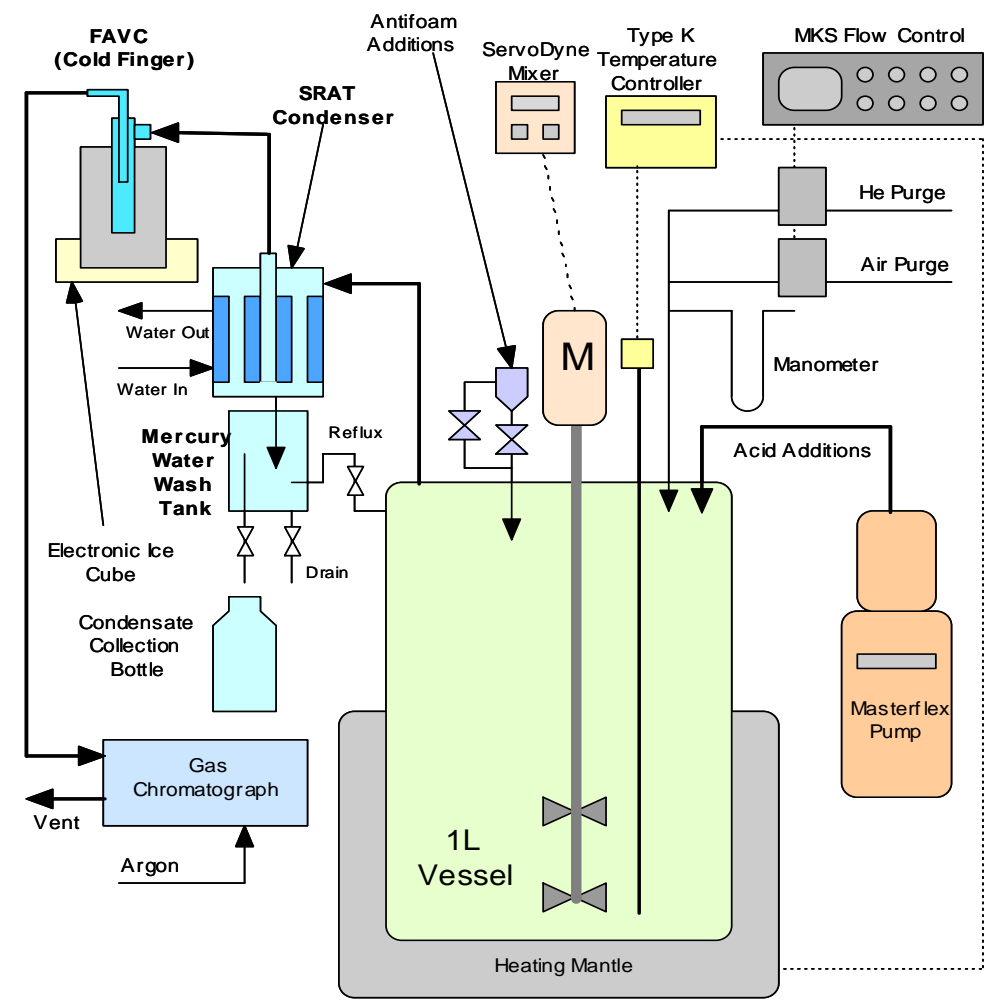

Figure 3-1. Schematic of SRAT Equipment Set-Up

Off-gas concentrations of hydrogen, oxygen, nitrogen, nitrous oxide, and carbon dioxide concentrations were measured during the experiments using in-line instrumentation (an Agilent 3000 series micro GC). Helium was introduced at a concentration of $0.5 \%$ of the total air purge as an inert tracer gas so that total amounts of generated gas and peak generation rates could be calculated. During the runs, the kettle was visually monitored to observe reactions that were occurring for signs of foaming, air entrainment, rheology changes, loss of heat transfer capabilities, and off-gas carryover. Observations are discussed in Sections 3.2 (SRAT cycle) and 3.3 (SME cycle).

Concentrated nitric acid (50-wt $\%)$ and formic acid (90-wt $\%)$ were used to acidify the sludge and perform neutralization and reduction reactions during processing. The amounts of acid to add were determined using the existing DWPF acid addition equation in the 3/12/2009 version of the SRNL acid calculation spreadsheet. The split of the acid was determined using the latest Reduction/Oxidation (REDOX) equation. ${ }^{14}$ To account for the reactions and anion destructions that occur during processing, assumptions about nitrite destruction, nitrite-to-nitrate conversion, and formate destruction were made based on results from SB7b simulant CPC testing. Acid stoichiometry and reflux time were also based on CPC processing of SB7b simulant sludge slurry. 


\subsection{SRAT Cycle}

This section contains details of the SRAT cycle, including a discussion of a portion of the SRAT receipt characterization. It should be noted that the SRAT receipt sample is the Tank $40 \mathrm{SB} 7 \mathrm{~b}$ sample described in the previous section. This section contains additional characterization results, specifically anions, carbonate, and total base on a slurry basis, rather than on a supernatant basis.

\subsubsection{SRAT Receipt Characterization and Acid Calculation}

SRAT cycle initiation was preceded by an acid calculation. Acid calculation inputs are presented in Table 3-2. Many of the inputs (e.g., density, wt \% solids) have been presented in the previous section. Anions, total inorganic carbon (TIC), and total base for the acid calculation were determined from water dilutions of slurry samples, while these analytes are presented above from supernatant analysis.

Table 3-2 contains two analyses of the SRAT receipt material. Based on the original analysis, significantly more acid was needed than calculated to destroy nitrite. To determine if the need for more acid was a result of unexpected sludge behavior or errors in the acid calculation inputs, several inputs were remeasured - anions, total inorganic carbon, and total base. Slurry was diluted in the second analysis as in the original analysis with the exception of total base.

In the second analysis, the slurry total base was determined by an in-Cells titration, which allowed more sample to be used in the titration. When total base is determined by AD, nominally $1.5 \mathrm{~g}$ of slurry is diluted to $50 \mathrm{~mL} ; 5 \mathrm{~mL}$ of diluted sample is submitted or approximately $0.15 \mathrm{~g}$ of slurry. Because of the small amount of actual slurry, there is also potential that a representative amount of solids is not submitted and titrated by AD. With an in-Cell titration, the total $1.5 \mathrm{~g}$ can be titrated.

Acid calculation results are presented in Table 3-3. Excess acid using both the original results and reanalyzed results are given. As discussed in Section 3.2.2 below, the SRAT cycle was completed in several stages, as more acid was added as it was determined that nitrite was not destroyed to below the target of $1,000 \mathrm{mg} / \mathrm{kg}$ SRAT product slurry. Based on the original analysis, analytical results (nitrite in SRAT product samples) suggest that the original analyses (specifically the total base) were in error. Excess acid was not significantly above $100 \%$, using the second analyses, until the third stage of acid addition. It is important to note that in all stages, the split of nitric and formic acids was set to maintain a redox of 0.2 . 
Table 3-2. Acid Calculation Inputs

\begin{tabular}{|c|c|c|c|}
\hline Input & $\begin{array}{l}\text { Original SRAT } \\
\text { Receipt Results }\end{array}$ & $\begin{array}{c}\text { Reanalyzed } \\
\text { SRAT Receipt } \\
\text { Results } \\
\end{array}$ & Units \\
\hline SRAT Receipt Mass & 1,120 & $*$ & g slurry \\
\hline SRAT Receipt Weight \% Total Solids & 16.1 & $*$ & wt $\%$ \\
\hline SRAT Receipt Weight \% Calcined Solids & 11.8 & $*$ & wt \% \\
\hline SRAT Receipt Weight \% Insoluble Solids & 10.6 & * & wt $\%$ \\
\hline SRAT Receipt Density & 1.12 & $*$ & kg/L slurry \\
\hline SRAT Receipt Supernatant Density & 1.06 & $*$ & $\mathrm{~kg} / \mathrm{L}$ supernatant \\
\hline SRAT Receipt Nitrite & 9,060 & 10,300 & $\mathrm{mg} / \mathrm{kg}$ slurry \\
\hline SRAT Receipt Nitrate & 5,330 & 5,570 & $\mathrm{mg} / \mathrm{kg}$ slurry \\
\hline SRAT Receipt Oxalate & 3,090 & 3,330 & $\mathrm{mg} / \mathrm{kg}$ slurry \\
\hline $\begin{array}{l}\text { SRAT Receipt Slurry TIC (treated as } \\
\text { carbonate) }\end{array}$ & 793 & 972 & $\mathrm{mg} / \mathrm{kg}$ slurry \\
\hline Fresh Supernatant TIC (treated as carbonate) & 1,050 & $*$ & $\mathrm{mg} / \mathrm{L}$ supernatant \\
\hline $\begin{array}{l}\text { SRAT Receipt Hydroxide (Base Equivalents) } \\
\mathrm{pH}=7\end{array}$ & $0.38^{\dagger}$ & $0.49^{\dagger}$ & $\begin{array}{l}\text { Equiv Moles } \\
\text { Base/L slurry } \\
\end{array}$ \\
\hline SRAT Receipt Manganese & 4.11 & * & $\begin{array}{l}\text { wt } \% \text { calcined } \\
\text { basis }\end{array}$ \\
\hline SRAT Receipt Mercury & 1.35 & $*$ & wt $\%$ dry basis \\
\hline SRAT Receipt Magnesium & 0.39 & * & $\begin{array}{l}\text { wt } \% \text { calcined } \\
\text { basis }\end{array}$ \\
\hline SRAT Receipt Calcium & 0.87 & $*$ & $\begin{array}{l}\text { wt } \% \text { calcined } \\
\text { basis }\end{array}$ \\
\hline $\begin{array}{l}\text { Conversion of Nitrite to Nitrate in SRAT } \\
\text { Cycle }\end{array}$ & 15 & $*$ & $\begin{array}{l}\text { gmol } \mathrm{NO}_{3}{ }^{-} / 100 \\
{\text { gmol } \mathrm{NO}_{2}^{-}}^{-}\end{array}$ \\
\hline $\begin{array}{l}\text { Destruction of Nitrite in SRAT and SME } \\
\text { cycle }\end{array}$ & 100 & $*$ & $\begin{array}{l}\% \text { of starting } \\
\text { nitrite destroyed }\end{array}$ \\
\hline Destruction of Formic acid charged in SRAT & 15 & * & $\begin{array}{l}\% \text { formate } \\
\text { converted to } \mathrm{CO}_{2} \\
\text { etc. }\end{array}$ \\
\hline Destruction of Oxalate charged & 2 & $*$ & $\begin{array}{l}\% \text { of total oxalate } \\
\text { destroyed }\end{array}$ \\
\hline $\begin{array}{l}\text { Percent Acid in Excess Stoichiometric Ratio } \\
\text { (Koop. Min Acid Eqn) }\end{array}$ & 110 & $*$ & $\%$ \\
\hline SRAT Product Target Solids & 25 & $*$ & $\mathrm{Wt} \%$ \\
\hline REDOX Target & 0.20 & $*$ & $\mathrm{Fe}^{+2} / \Sigma \mathrm{Fe}$ \\
\hline
\end{tabular}

* These analyses were not repeated, and these assumptions were not changed.

${ }^{\dagger}$ The first total base result $(0.38 \mathrm{~mol} / \mathrm{L})$ was determined by a titration using a small amount of diluted slurry. The second result $(0.49 \mathrm{~mol} / \mathrm{L})$ was determined by an in-Cell titration of $1.5 \mathrm{~g}$ of slurry diluted with $20 \mathrm{~g}$ of water.

$\$$ This result was obtained from a water dilution of slurry. It is comparable to an acid dissolution of SRAT receipt $-2,810 \mathrm{mg} / \mathrm{kg}$ (See Reference 15). Oxalate from water dilution of SME product was significantly les 
SRNL-STI-2011-00548

Revision 0

Table 3-3. Acid Calculation Results Based on One Liter of SRAT Receipt Slurry

\begin{tabular}{|c|c|c|}
\hline & $\begin{array}{l}\text { Acid Calculation Results } \\
\text { Based on Original SRAT } \\
\text { Receipt Results }\end{array}$ & $\begin{array}{c}\text { Acid Calculation Results } \\
\text { Based on Reanalyzed SRAT } \\
\text { Receipt Results }\end{array}$ \\
\hline Hsu Total Stoichiometric Acid required (mol) * & 0.824 & 0.990 \\
\hline $\begin{array}{l}\text { Koopman Minimum Stoichiometric Acid required } \\
(\mathrm{mol}) *\end{array}$ & 0.918 & 1.06 \\
\hline \multicolumn{3}{|c|}{ Stage 1} \\
\hline Total Acid Added (mol) & \multicolumn{2}{|c|}{1.01} \\
\hline Stoichiometric Acid Hsu Eqn (\%) & 123 & 102 \\
\hline Stoichiometric Acid Koopman Minimum Eqn. (\%) & 110 & 95 \\
\hline \multicolumn{3}{|c|}{ Stage 2} \\
\hline Acid added (mol) & \multicolumn{2}{|c|}{1.06} \\
\hline Stoichiometric Acid Hsu Eqn (\%) & 129 & 107 \\
\hline Stoichiometric Acid Koopman Minimum Eqn. (\%) & 115 & 100 \\
\hline \multicolumn{3}{|c|}{ Sage 3} \\
\hline Acid added (mol) & \multicolumn{2}{|c|}{1.15} \\
\hline Stoichiometric Acid Hsu Eqn (\%) & 139 & 116 \\
\hline Stoichiometric Acid Koopman Minimum Eqn. (\%) & 125 & 108 \\
\hline
\end{tabular}

* See Reference 16 for a description of the acid equations. Note that in the document, Equation 1 is the Hsu Total Stoichiometric Acid equation, and Equation 2 is the Koopman Minimum Stoichiometric Acid equation.

\subsubsection{SRAT Cycle Discussion and Results}

The SRAT cycle was completed in three stages. Stage 1 began with acid addition at $123 \%$ acid stoichiometry based on the Hsu acid equation and the original SRAT receipt analyses. Due to resource issues, Stage 1 was completed over two days. On day one, nitric and formic acids were added. On Day 2, the sludge was boiled (water was removed to concentrate the total solids followed by additional boiling to steam strip mercury). Total boiling time was 12 hours. The resulting SRAT product was characterized. Highlights follow:

- Mercury Removal - Mercury in the SRAT product total solids was $0.21 \mathrm{wt} \%$. This is below the $0.8 \mathrm{wt} \%$ DWPF target for mercury.

- Nitrite destruction - Nitrite was not destroyed to below the DWPF limit of $1,000 \mathrm{mg} / \mathrm{kg}$. The measured nitrite was $2,500 \mathrm{mg} / \mathrm{kg}$ slurry.

- Hydrogen generation peaked at $0.014 \mathrm{lb} / \mathrm{h}$ (DWPF scale), four hours into boiling.

- Antifoam Addition - 300 ppm antifoam was added prior to acid addition (200 ppm on the day of the planned start and $100 \mathrm{ppm}$ the following day at the actual start). $100 \mathrm{ppm}$ was added between nitric and formic acid additions. $500 \mathrm{ppm}$ was added just prior to boiling. No evidence of foaming was observed. Antifoam was from Siovation Lot\#111128-0613 (produced with new antifoam purchase specification).

Because nitrite was not destroyed, additional acid was added followed by eight hours of boiling (Stage 2). Total acid was equivalent to an increase from $123 \%$ to $128 \%$, based on the Hsu acid equation and the original SRAT receipt characterization. Again, nitrite was still above 1,000 $\mathrm{mg} / \mathrm{kg}$ slurry (approximately $1,800 \mathrm{mg} / \mathrm{kg}$ slurry). During this time of processing no hydrogen was detected (detection limit is approximately $0.01 \mathrm{vol} \%$ ). No antifoam was added and foaming was not observed. 
Again, because nitrite was still above the DWPF limit, additional acid was added to the SRAT followed by eight hours of boiling (Stage 3). Total acid was equivalent to an increase from 128\% to $139 \%$, based on the Hsu acid equation and the original SRAT receipt characterization. Nitrite concentration was finally reduced to below $1,000 \mathrm{mg} / \mathrm{kg}$ slurry $(320 \mathrm{mg} / \mathrm{kg}$ slurry). During this time of processing, hydrogen peaked at $0.012 \mathrm{lb} / \mathrm{h} .100 \mathrm{ppm}$ antifoam was added prior to acid addition, and foaming was not observed.

It has not been necessary to add $\sim 140 \%$ of the Hsu stoichiometric acid requirement to achieve nitrite destruction before SC-12 which led SRNL to suspect there might be errors in the acid calculation inputs. Reanalysis of the SRAT receipt sample resulted in small increases in the initial nitrite and TIC concentrations that increased the stoichiometric requirement by about $7 \%$. The direct titration of diluted slurry, however, resulted in a significantly higher base equivalents value than had been determined for the original sample. Based on the reanalysis of the SRAT receipt sample, a stoichiometric factor of $116 \%$ was sufficient to destroy nitrite, consistent with simulant testing. Reanalysis and the acid calculation are discussed in 3.2.1 above, and a table showing acid stoichiometry using both the original and reanalyzed SRAT receipt analyses is given in Table 3-3.

SRAT product analytical results are given in Table 3-4. Samples were only measured for anions after Stage 2 and Stage 3. Acid stoichiometry based on both the original and reanalyzed SRAT receipt characterization is given in Table 3-2 above.

Table 3-4. SRAT Product Analytical Results

\begin{tabular}{||l|c|c|c||}
\hline Analysis & $\begin{array}{c}\text { SRAT Product } \\
\text { Stage 1 }\end{array}$ & $\begin{array}{c}\text { SRAT Product } \\
\text { Stage 2 }\end{array}$ & $\begin{array}{c}\text { SRAT Product } \\
\text { Stage 3 }\end{array}$ \\
\hline Wt \% Total Solids & 23.6 & NM & NM \\
\hline Wt \% Dissolved Solids & 11.8 & NM & NM \\
\hline Wt \% Insoluble Solids & 13.3 & NM & NM \\
\hline Wt \% Calcined Solids & 17.7 & NM & NM \\
\hline Slurry Density (g/mL) & 1.15 & NM & NM \\
\hline Supernatant Density (g/mL) & 1.08 & NM & NM \\
\hline Formate (mg/kg slurry) & 41,700 & 44,900 & 55,000 \\
\hline Nitrite (mg/kg slurry) & 2,520 & 1,900 & 269 \\
\hline Nitrate (mg/kg slurry) & 21,400 & 23,300 & 27,300 \\
\hline Oxalate (mg/kg slurry) $*$ & 1,100 & $\mathrm{NM}$ & $\mathrm{NM}$ \\
\hline Hg (wt \% of total solids) & 0.21 & $\mathrm{NM}$ & $\mathrm{NM}$ \\
\hline
\end{tabular}

$\mathrm{NM}=$ not measured

* This result was obtained from an acid dissolution of SRAT product (See Reference 15). Oxalate from water dilution of SRAT product was significantly less $-1,100 \mathrm{mg} / \mathrm{kg}$ slurry.

\subsection{SME Cycle}

The SME cycle began with the simulation of the addition/removal of five canisters of frit decon water. This process corresponded to approximately ten hours of boiling. Frit and formic acid were then added, followed by dewatering. Hydrogen generation peaked at $0.022 \mathrm{lb} / \mathrm{h}$ at the conclusion of the cycle. $100 \mathrm{ppm}$ antifoam was added prior to the addition of the frit and formic acid. Foaming was not observed. At the conclusion of the cycle, an analytical sample was taken. Results are presented in Table 3-5. A portion of the SME product was vitrified and characterized (see 4.0 below). 
Table 3-5. SME Product Analytical Results

\begin{tabular}{||l|c|}
\hline Analysis & Result \\
\hline Wt \% Total Solids & 46.7 \\
\hline Wt \% Dissolved Solids & 13.9 \\
\hline Wt \% Insoluble Solids & 38.1 \\
\hline Slurry Density (g/mL) & 1.45 \\
\hline Supernatant Density (g/mL) & 1.10 \\
\hline Formate (mg/kg slurry) & 30,700 \\
\hline Nitrite (mg/kg slurry) & $<400$ \\
\hline Nitrate (mg/kg slurry) & 20,200 \\
\hline Oxalate (mg/kg slurry) $*$ & 3,600 \\
\hline Inorganic Carbon (mg/kg slurry) & 749 \\
\hline Organic Carbon (mg/kg slurry) & 10,200 \\
\hline
\end{tabular}

* This result was obtained from an acid dissolution of SME product (See Reference 15). Oxalate from water dilution of SME product was significantly less - $390 \mathrm{mg} / \mathrm{kg}$ slurry).

\subsection{Offgas Results}

Peak hydrogen, carbon dioxide, and nitrous oxide concentrations and generation rates are presented in Table 3-6 (SRAT cycle) and Table 3-7 (SME cycle). Offgas data is presented graphically in Figure 3-2 and Figure 3-3. Only Stage 1 of the SRAT cycle (acid addition followed by twelve hours of reflux) is shown, as this was the stage with the maximum hydrogen, carbon dioxide, and nitrous oxide generation rates.

Table 3-6. SRAT Cycle Peak Gas Concentrations and Generation Rates

\begin{tabular}{|l|c|c|}
\hline & $\begin{array}{c}\text { Maximum Observed } \\
\text { Concentration } \\
\mathbf{( m o l \% )}\end{array}$ & $\begin{array}{c}\text { Maximum Observed } \\
\text { DWPF-Scale Generation } \\
\text { Rate } \\
\mathbf{( l b / h )}\end{array}$ \\
\hline Hydrogen & 0.017 & 0.012 \\
\hline Carbon Dioxide & 18 & 366 \\
\hline Nitrous Oxide & 1.6 & 30 \\
\hline
\end{tabular}

Table 3-7. SME Cycle Peak Gas Concentrations and Generation Rates

\begin{tabular}{|l|c|c||}
\hline & $\begin{array}{c}\text { Maximum Observed } \\
\text { Concentration } \\
(\mathbf{m o l} \%)\end{array}$ & $\begin{array}{c}\text { Maximum Observed } \\
\text { DWPF-Scale Generation } \\
\text { Rate } \\
\text { (lb/h) }\end{array}$ \\
\hline Hydrogen & 0.085 & 0.022 \\
\hline Carbon Dioxide & 4.5 & 26 \\
\hline Nitrous Oxide & 0.081 & 0.46 \\
\hline
\end{tabular}


SRNL-STI-2011-00548

Revision 0

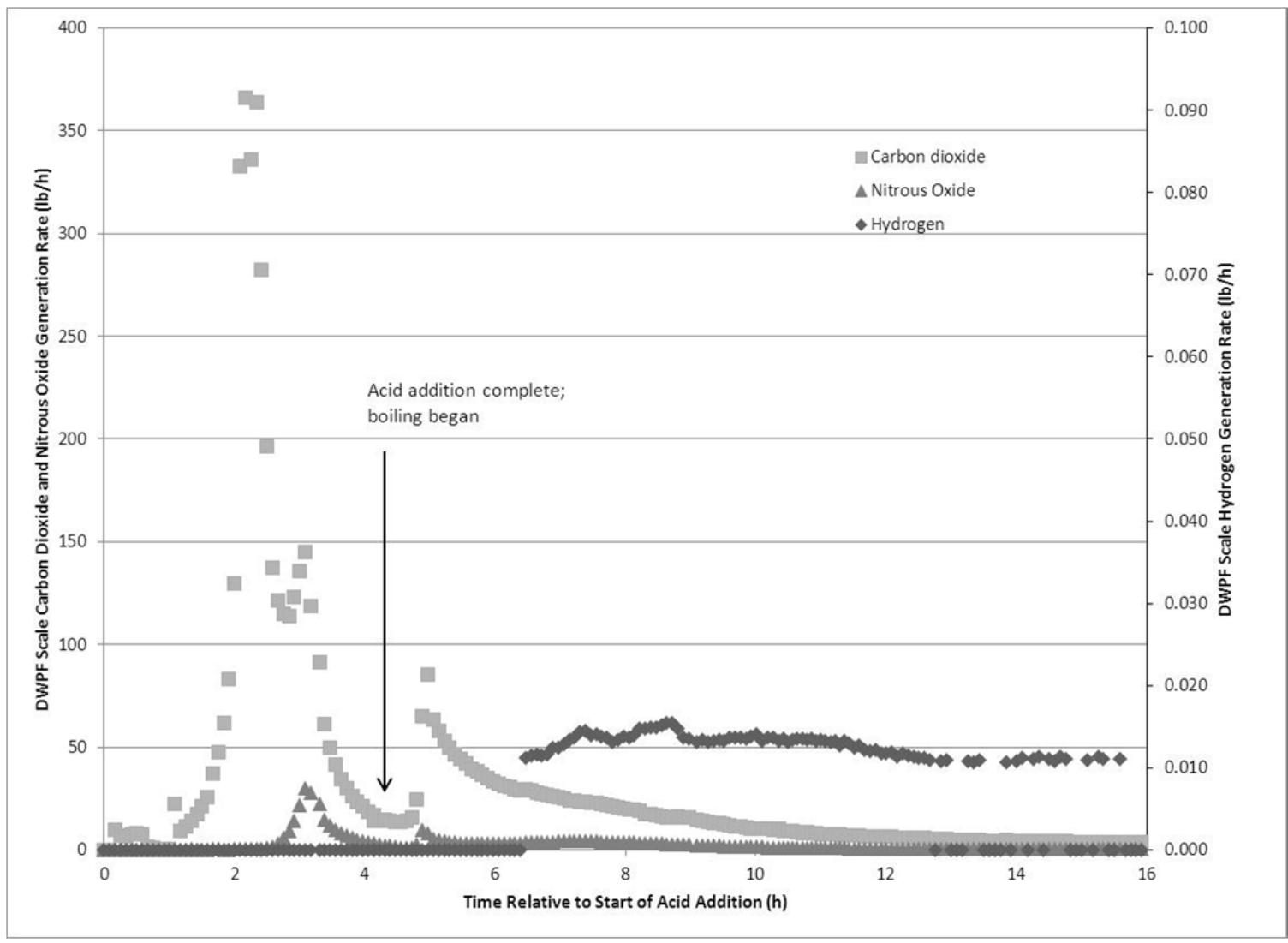

Figure 3-2. SRAT Cycle Offgas - Stage 1 


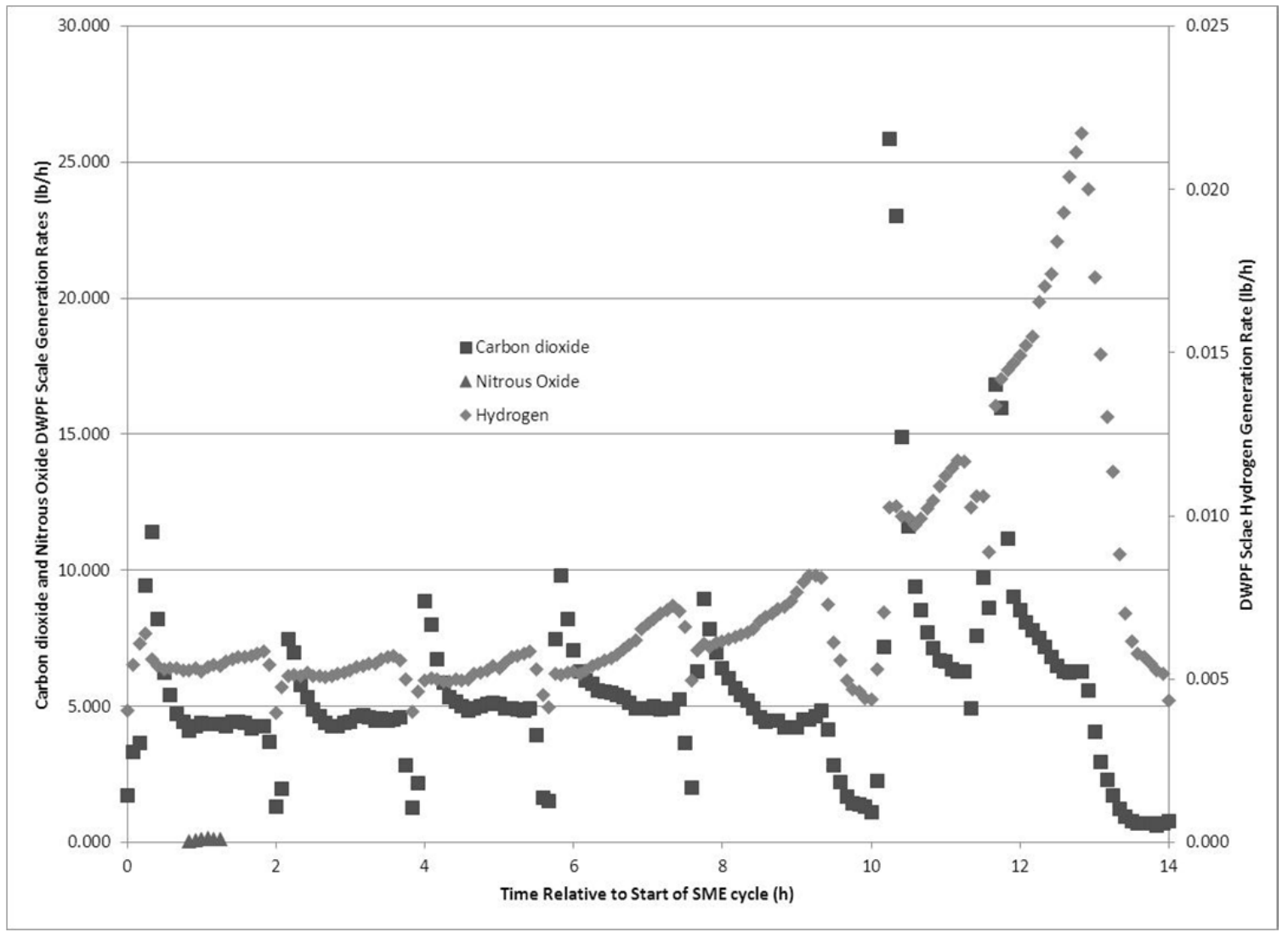

Figure 3-3. SME Cycle Offgas

\subsection{Anion Destruction}

Presented in Table 3-8 are cumulative anion destruction and conversion calculations based on analytical results following each stage of processing. Note that these calculations are approximate, as some of the inputs to the calculation are estimated (specifically the SRAT and SME product masses). As expected, overall nitrite destruction increased through each successive stage as more acid was added. It is interesting to note that formate destruction decreased during each stage of SRAT processing. Low formate destruction is consistent with the lack of hydrogen observed during SRAT processing. However, it is likely that at least some formate was destroyed and that no formate was created, as the decrease in formate destruction suggests. Nitrite to nitrate conversion exceeded the projected $15 \%$ used in the acid calculation.

Table 3-8. Cumulative Anion Destruction and Conversion

\begin{tabular}{|l|c|c|c||}
\hline Product Sample & $\begin{array}{c}\text { Nitrite } \\
\text { Destruction } \\
(\mathbf{\%})\end{array}$ & $\begin{array}{c}\text { Formate } \\
\text { Destruction } \\
(\mathbf{\% )}\end{array}$ & $\begin{array}{c}\text { Nitrite to } \\
\text { Nitrate } \\
\text { Conversion } \\
(\mathbf{\%})\end{array}$ \\
\hline Stage 1 & 81 & 7 & 22 \\
\hline Stage 2 & 86 & 6 & 29 \\
\hline Stage 3 & 98 & 0 & 42 \\
\hline SME Cycle & NA & 35 & 20 \\
\hline
\end{tabular}




\subsection{Rheology}

Rheological properties of the SRAT Receipt, SRAT Product, and SME Product were determined from analytical samples. It should be noted that the SRAT product results are based on the analytical sample taken after Stage 1, before all required acid was added. Results, along with DWPF design bases, are presented in Table 3-9. Flow curves are shown in Appendix B. The SRAT receipt and SRAT product results were determined from the average of two measurements. The SME product was determined from one measurement.

In comparing results to design bases, the SRAT receipt sample results are well within targets. SRAT product results exceed design bases, however, it is expected that the rheological properties would be improved with the appropriate amount of acid. With the high consistency of the SME product, concentration to beyond $46 \mathrm{wt} \%$ total solids is not recommended.

Table 3-9. SRAT and SME SB7b Rheology Data

\begin{tabular}{||c|c|c|c|c|}
\hline Sample & $\begin{array}{c}\text { Wt\% Total } \\
\text { Solids }\end{array}$ & $\begin{array}{c}\text { Wt\% Insoluble } \\
\text { Solids }\end{array}$ & $\begin{array}{c}\text { Consistency } \\
\text { (cP) }\end{array}$ & $\begin{array}{c}\text { Yield Stress } \\
\text { (Pa) }\end{array}$ \\
\hline $\begin{array}{c}\text { Washed Sludge Slurry } \\
\text { (Design Basis) }^{\dagger}\end{array}$ & $13-19$ & $N A$ & $4-12$ & $2.5-10$ \\
\hline $\begin{array}{c}\text { SRNL Prepared SB7b } \\
\text { SRAT Receipt }\end{array}$ & 16.1 & 10.6 & 6.5 & 4.0 \\
\hline $\begin{array}{c}\text { SRAT Slurry } \\
\text { (Design Basis) }^{\dagger}\end{array}$ & $18-25$ & $N A$ & $5-12$ & $1.5-5$ \\
\hline SB7b SRAT Product & 22.6 & 13.3 & 13 & 6.7 \\
\hline $\begin{array}{c}\text { Melter Feed } \\
\text { (Design Basis) }^{\ddagger}\end{array}$ & $40-50$ & $N A$ & $10-40$ & $2.5-15$ \\
\hline SB7b SME Product & 46.7 & 38.1 & 56 & 21 \\
\hline
\end{tabular}

${ }^{\dagger}$ From Basic Data Report: Defense Waste Processing Facility Sludge Plant; Savannah River Plant 200-S Area, DPSP-80-1033, Revision 10 (Ref. 17.

${ }^{\ddagger}$ From Preliminary Melter Feed Rheology Study, WSRC-RP-92-01240 Ref. 18). .

\subsection{Glass Fabrication and PCT}

Presented in this section are observations and key results of the SRNL-prepared Tank 40 SB7b SME derived glass sample. Glass composition and Product Consistency Test (PCT) results, as well as predicted property information, are presented as requested by the DWPF via a TTR ${ }^{1}$ and governed by a TTQAP. ${ }^{2}$ A description of the glass fabrication is given below, followed by tables with analytical results.

The SB7b Qualification sample was subjected to the DWPF CPC simulations as reported in previous sections. Frit 702 was used during the SME cycle as was recommended for process simulations in a prior memo. ${ }^{19}$ The frit addition was based on a target waste loading of $36 \mathrm{wt} \%$ calcined sludge. A sample of the SME product was dried and vitrified, with the resulting glass characterized and evaluated using the PCT. 


\subsection{Glass Fabrication}

Approximately $140 \mathrm{~g}$ of SME product was divided into nearly equal portions amongst 4 crucibles and dried overnight at $110^{\circ} \mathrm{C}$. After drying, the first portion was gradually heated to $1150{ }^{\circ} \mathrm{C}$ in a $\mathrm{Pt} / \mathrm{Au}$ crucible in an electrically heated furnace. Upon reaching $1150^{\circ} \mathrm{C}$, the sample was held at temperature for approximately 30 minutes. The remaining portions were then added incrementally, allowing the crucible to return to temperature between each addition, resulting in a total time at $1150{ }^{\circ} \mathrm{C}$ of 4 hours. The crucible was removed from the furnace at temperature and bottom quenched (cooled) in a shallow pan of water, ensuring no water contacted the glass. The resulting glass appeared black and shiny, without the presence of a sulfate layer and was used for the glass chemical and PCT analyses.

\subsection{Glass Dissolution Methods and Analyses}

To support compositional analysis, a portion of the SB7b Qualification Glass had to be dissolved. In order to enhance dissolution, approximately $4 \mathrm{~g}$ of the glass was crushed and ground using agate cups, balls and caps in a mechanical pulverizing mixer mill. The glass was sieved and only the portion that passed through a 200 mesh $(<75 \mu \mathrm{m})$ brass sieve was used for the dissolutions. Weighed amounts (nominally $0.25 \mathrm{~g}$ ) of the crushed glass were then dissolved remotely by two different methods to ensure that all the elements of interest were dissolved and could be analyzed in at least one of the preparations. The two methods were a sodium peroxide fusion (PF) at $675{ }^{\circ} \mathrm{C}$ followed by a $\mathrm{HNO}_{3}$ uptake, and a mixed acid dissolution (MA) in sealed vessels at $115^{\circ} \mathrm{C}$ using a combination of $\mathrm{HF}, \mathrm{HCl}$, and $\mathrm{HNO}_{3}$ acids. Boric acid was added to this latter dissolution method to complex excess fluoride. The solutions of the dissolved glass were diluted to known volumes so that approximately $15 \mathrm{~mL}$ aliquots could be safely removed from the Shielded Cells without exposing personnel to excess radiation.

The aliquots were then submitted to AD where they were analyzed by ICP-AES. Aliquots of the peroxide fusion dissolutions were also submitted for ICP-MS analysis and radioactive counting techniques. Concurrent with each set of dissolutions in the Shielded Cells, three samples of the Analytical Reference Glass (ARG-1) were also dissolved to determine if the dissolutions were complete and the resulting analyses accurate. A multi-element standard containing known concentrations of $\mathrm{Al}, \mathrm{Fe}, \mathrm{Mn}, \mathrm{Na}, \mathrm{Ni}$, and $\mathrm{S}$ was also submitted with each set of samples sent to $\mathrm{AD}$.

\subsection{Standard ASTM 1285 Leach Test Procedure}

The durability of the SB7b Qualification Glass was measured by following Test Method A of the ASTM 1285 standard nuclear waste glass leach test. ${ }^{20}$ This test is commonly referred to as the PCT. The purpose of the PCT was to confirm that the SB7b Qualification Glass had a durability that met the criterion specified by the Waste Acceptance Product Specification (WAPS) for repository acceptance. ${ }^{21}$ WAPS 1.3 specifies that the mean concentrations of $\mathrm{B}, \mathrm{Li}$, and $\mathrm{Na}$ in the leachate, after normalizing for the concentrations in the glass, shall each be less than those of the Environmental Assessment (EA) glass. ${ }^{22}$ These normalized concentrations represent the concentration of leached glass in PCT solutions assuming all elements in the glass are soluble. DWPF complies with this criterion by demonstrating that the mean PCT results are at least two standard deviations below the mean PCT results of the EA glass.

The ASTM 1285 Test Method A is a crushed glass (-100 to +200 mesh or 75 to $149 \mu \mathrm{m})$ leach test at $90{ }^{\circ} \mathrm{C}$ for 7 days using deionized (DI) water in sealed stainless steel vessels. The test was performed in quadruplicate for the SB7a Qualification Glass. Duplicate blanks and triplicate samples of the standard glass [Approved Reference Material (ARM)] and triplicate samples of the EA glass were also tested with the SB7b Qualification glass samples. In the PCT, $10 \mathrm{~mL}$ of DI 
water are used for each gram of glass. Nominally $1.7 \mathrm{~g}$ of glass and $17 \mathrm{~mL}$ of DI water were used in stainless steel vessels that were sealed tightly and weighed in order to ensure enough leachate was generated for analysis. After 7 days at $90{ }^{\circ} \mathrm{C}$, the stainless steel vessels were removed from the oven, allowed to cool, weighed to determine water loss, and then opened. Due to the radioactivity of the glass, the initial portion of the test was performed remotely in a Shielded Cell using manipulators. The leachates from each vessel were then decanted into a clean scintillation vials. The radioactivity levels of the leachates were low enough so they could be transported to a radiochemical hood where they could be handled directly. The $\mathrm{pH}$ of each leachate was measured and then filtered through a $0.45 \mu \mathrm{m}$ filter and acidified to 1 volume percent $\mathrm{HNO}_{3}$. The leachates were then diluted and submitted to $\mathrm{AD}$, where the concentrations of $\mathrm{B}, \mathrm{Na}, \mathrm{Li}, \mathrm{Si}$ and $\mathrm{U}$, were determined using ICP-AES.

\subsection{Glass Fabrication and PCT Results and Discussion}

Table 4-1 lists the oxide composition of the SB7b Qualification Glass on a wt \% basis. All elements specifically requested in the TTR, ${ }^{1}$ along with elements necessary for Product Composition Control System (PCCS) calculations (e.g., $\mathrm{Cu}$ and $\mathrm{Nd}$ ), are reported in this table. Essentially all of the $\mathrm{B}, \mathrm{Li}$ and $\mathrm{Si}$ and a portion of the $\mathrm{Na}$ are from the glass frit added to the SRAT product in order to prepare the glass. The frit used was Frit 702, which has a nominal composition of $76 \mathrm{wt} \% \mathrm{SiO}_{2}, 8$ wt $\% \mathrm{~B}_{2} \mathrm{O}_{3}, 10 \mathrm{wt} \% \mathrm{Li}_{2} \mathrm{O}$ and 6 wt $\% \mathrm{Na}_{2} \mathrm{O}$. This frit was recommended for use during the SME cycle based on a Measurement Acceptability Region (MAR) assessment completed on the analyzed SRAT Receipt material. ${ }^{19}$ Depending upon the element, the results in Table 4-1 represent an average of up to eight measurements (actual number of measurements noted in table) resulting from the glass dissolution and analysis techniques. 
Table 4-1. Determined Oxide Concentrations Measured in SB7b Qualification Glass

\begin{tabular}{|c|c|c|c|c|c|}
\hline Oxide & Wt $\%$ & $\begin{array}{c}\text { Est. Std. Unc. } \\
\text { (1-Sigma) }\end{array}$ & $\begin{array}{l}\text { \# Samples } \\
\text { Averaged }\end{array}$ & $\begin{array}{l}\text { Digestion } \\
\text { Methods }^{\text {a }}\end{array}$ & $\begin{array}{c}\text { Detection } \\
\text { Method }\end{array}$ \\
\hline$\overline{\mathrm{Ag}_{2} \mathrm{O}}$ & 0.008 & 0.0003 & $\overline{44}$ & $\overline{P \mathrm{PF}}$ & ICP-MS \\
\hline $\mathrm{Al}_{2} \mathrm{O}_{3}$ & 7.284 & 0.0894 & 8 & $\mathrm{PF} / \mathrm{MA}$ & ICP-AES \\
\hline $\mathrm{B}_{2} \mathrm{O}_{3}$ & 4.870 & 0.0481 & 4 & $\mathrm{PF}$ & ICP-AES \\
\hline $\mathrm{BaO}$ & 0.047 & 0.0004 & 8 & $\mathrm{PF} / \mathrm{MA}$ & ICP-AES \\
\hline $\mathrm{BeO}$ & 0.000 & 0.0000 & 4 & MA & ICP-AES \\
\hline $\mathrm{CaO}$ & 0.417 & 0.0032 & 4 & MA & ICP-AES \\
\hline $\mathrm{CdO}$ & 0.013 & 0.0002 & 8 & $\mathrm{PF} / \mathrm{MA}$ & ICP-AES \\
\hline $\mathrm{Ce}_{2} \mathrm{O}_{3}$ & 0.057 & 0.0020 & 4 & $\mathrm{PF}$ & ICP-MS \\
\hline $\mathrm{CoO}$ & 0.008 & 0.0001 & 4 & MA & ICP-AES \\
\hline $\mathrm{Cr}_{2} \mathrm{O}_{3}$ & 0.068 & 0.0005 & 8 & $\mathrm{PF} / \mathrm{MA}$ & ICP-AES \\
\hline $\mathrm{CuO}$ & 0.217 & 0.0022 & 8 & PF/MA & ICP-AES \\
\hline $\mathrm{Fe}_{2} \mathrm{O}_{3}$ & 8.603 & 0.0599 & 8 & PF/MA & ICP-AES \\
\hline $\mathrm{Gd}_{2} \mathrm{O}_{3}$ & 0.037 & 0.0005 & 8 & $\mathrm{PF} / \mathrm{MA}$ & ICP-AES \\
\hline $\mathrm{K}_{2} \mathrm{O}$ & 0.031 & 0.0010 & 4 & MA & ICP-AES \\
\hline $\mathrm{La}_{2} \mathrm{O}_{3}$ & 0.038 & 0.0010 & 8 & $\mathrm{PF} / \mathrm{MA}$ & ICP-AES \\
\hline $\mathrm{Li}_{2} \mathrm{O}$ & 6.665 & 0.0395 & 8 & PF/MA & ICP-AES \\
\hline $\mathrm{MgO}$ & 0.215 & 0.0028 & 8 & $\mathrm{PF} / \mathrm{MA}$ & ICP-AES \\
\hline $\mathrm{MnO}$ & 1.679 & 0.0142 & 8 & $\mathrm{PF} / \mathrm{MA}$ & ICP-AES \\
\hline $\mathrm{MoO}_{3}$ & 0.006 & 0.0001 & 4 & MA & ICP-AES \\
\hline $\mathrm{Na}_{2} \mathrm{O}$ & 11.977 & 0.0862 & 4 & MA & ICP-AES \\
\hline $\mathrm{Nd}_{2} \mathrm{O}_{3}$ & 0.110 & 0.0019 & 4 & PF & ICP-MS \\
\hline $\mathrm{NiO}$ & 1.588 & 0.0131 & 8 & $\mathrm{PF} / \mathrm{MA}$ & ICP-AES \\
\hline $\mathrm{P}_{2} \mathrm{O}_{5}$ & 0.135 & 0.0029 & 4 & MA & ICP-AES \\
\hline $\mathrm{PbO}$ & 0.013 & 0.0013 & 4 & $\mathrm{PF}$ & ICP-MS \\
\hline $\mathrm{PdO}$ & 0.001 & 0.0000 & 4 & $\mathrm{PF}$ & ICP-MS \\
\hline $\mathrm{Rh}_{2} \mathrm{O}_{3}$ & 0.008 & 0.0006 & 4 & $\mathrm{PF}$ & ICP-MS \\
\hline $\mathrm{RuO}_{2}$ & 0.013 & 0.0004 & 4 & $\mathrm{PF}$ & ICP-MS \\
\hline $\mathrm{Sb}_{2} \mathrm{O}_{3}$ & 0.020 & 0.0009 & 4 & MA & ICP-AES \\
\hline $\mathrm{SiO}_{2}$ & 51.504 & 0.3534 & 4 & PF & ICP-AES \\
\hline $\mathrm{SnO}_{2}$ & 0.007 & 0.0003 & 4 & MA & ICP-AES \\
\hline $\mathrm{SO}_{4}{ }^{2-}$ & 0.345 & 0.0225 & 3 & MA & ICP-AES \\
\hline $\mathrm{SrO}$ & 0.024 & 0.0003 & 8 & PF/MA & ICP-AES \\
\hline $\mathrm{ThO}_{2}$ & 0.480 & 0.0199 & 4 & PF & ICP-AES \\
\hline $\mathrm{TiO}_{2}$ & 0.021 & 0.0011 & 8 & $\mathrm{PF} / \mathrm{MA}$ & ICP-AES \\
\hline $\mathrm{U}_{3} \mathrm{O}_{8}$ & 2.410 & 0.0520 & 4 & PF & ICP-MS \\
\hline $\mathrm{V}_{2} \mathrm{O}_{5}$ & $<0.0007$ & $\mathrm{~N} / \mathrm{A}$ & 4 & MA & ICP-AES \\
\hline $\mathrm{Y}_{2} \mathrm{O}_{3}$ & 0.014 & 0.0006 & 4 & PF & ICP-MS \\
\hline $\mathrm{ZnO}$ & 0.058 & 0.0009 & 8 & $\mathrm{PF} / \mathrm{MA}$ & ICP-AES \\
\hline $\mathrm{ZrO}_{2}$ & 0.137 & 0.0015 & 4 & MA & ICP-AES \\
\hline $\begin{array}{l}\text { Sum of } \\
\text { Oxides }\end{array}$ & 99.1 & & & & \\
\hline
\end{tabular}

${ }^{a} \mathrm{PF}=$ Peroxide Fusion dissolution method, MA = Mixed Acid dissolution method 
The measured SB7b Qualification Glass composition reported in Table 4-1 was used to predict the properties of the glass based on the PCCS models. The results are listed in Table 4-2. The predicted properties from this composition were then compared to SME acceptability criteria to evaluate whether this glass did indeed meet the DWPF processing and product quality constraints. Based on the measured composition, all of the predicted properties met the PCCS MAR criteria and a list of selected predicted properties are found in Table 4-2.

Table 4-2. PCCS Results for SB7b Qualification Glass

\begin{tabular}{|c|c|}
\hline PCCS Model & Predicted Value \\
\hline $\mathrm{B} \Delta \mathrm{G}_{\mathrm{p}}$ Value & -10.211 \\
\hline $\mathrm{NL}[\mathrm{B}(\mathrm{g} / \mathrm{L})]$ & 0.889 \\
\hline $\mathrm{T}_{\mathrm{L}}$ Prediction $\left({ }^{\circ} \mathrm{C}\right)$ & 903.4 \\
\hline Viscosity Prediction $(\mathrm{P})$ & 43.8 \\
\hline Nepheline Constraint Value & 0.728 \\
\hline $\mathrm{Al}_{2} \mathrm{O}_{3}(\mathrm{wt} \%)$ & 7.28 \\
\hline All PCCS MAR Criteria Met & yes \\
\hline
\end{tabular}

For the SB7b Qualification Glass, the waste loading was calculated based on the analyzed glass $\mathrm{Li}_{2} \mathrm{O}$ content and the targeted $\mathrm{Li}_{2} \mathrm{O}$ content of the Frit $702(10.0 \mathrm{wt} \%)$. Using these results yields a waste loading of $33.4 \mathrm{wt} \%$ which is only slightly lower than the targeted $36 \mathrm{wt} \% \mathrm{WL}$ and within the analytical error. Other calculations based upon the measured SRAT product composition and the measured SB7b Glass composition yield an average result of $33 \%$ WL. These results can be found in Table 4-3.

Table 4-3. Calculated Waste Loading

\begin{tabular}{||c|c|c|c|c||}
\hline \hline Oxide & $\begin{array}{c}\text { SB7b Glass } \\
\text { Measured } \\
\text { Concentration } \\
\text { (wt\%) }\end{array}$ & $\begin{array}{c}\text { Frit 702 } \\
\text { Target } \\
\text { Concentrati } \\
\text { on (wt\%) }\end{array}$ & $\begin{array}{c}\text { SRAT } \\
\text { Product } \\
\text { Measured } \\
\text { Concentrati } \\
\text { on (wt\%) }\end{array}$ & $\begin{array}{c}\text { Calculated } \\
\text { \% Waste } \\
\text { Loading }\end{array}$ \\
\hline \hline $\mathrm{Al}_{2} \mathrm{O}_{3}$ & 7.284 & 0 & 22.135 & 32.9 \\
\hline $\mathrm{Fe}_{2} \mathrm{O}_{3}$ & 8.603 & 0 & 27.016 & 31.8 \\
\hline $\mathrm{Li}_{2} \mathrm{O}$ & 6.665 & 10 & N/A & 33.4 \\
\hline $\mathrm{U}_{3} \mathrm{O}_{8}$ & 2.410 & 0 & 7.113 & 33.9 \\
\hline \multicolumn{5}{|c|}{ Average \% Waste Loading } \\
\hline
\end{tabular}

Quadruplicate samples of the SB7b Qualification Glass were subjected to the PCT along with triplicate blanks, triplicate samples of the ARM and the $\mathrm{EA}^{22}$ reference glass as prescribed by the ASTM procedure. ${ }^{20}$ The results for the reference glasses and the blanks indicated that the test was acceptable by ASTM standards. All vessels exhibited minimal to no water loss $(<5 \%$ relative water loss) during the course of the test. The blanks and leachates from the ARM reference glass all had elemental and normalized releases within the reference values. ${ }^{23}$ One 
replicate of EA exhibited anomalous results and was excluded from the calculation of normalized release rates as prescribed by the ASTM procedure. The remaining 2 EA leachates had elemental and normalized releases within the referenced value. Results for the averaged normalized releases, based on $\mathrm{B}, \mathrm{Na}, \mathrm{Li}, \mathrm{Si}$ and $\mathrm{U}$ (grams of normalized element per liter of PCT leachate) are given in Table 4-4. A table listing the ppm releases of the leachates tested and the $\mathrm{pH}$ of the individual leachates can be found in Appendix A, Table A1. The normalized releases for the SB7b Qualification Glass based on B, Na, Li and Si are more than an order of magnitude less than those for the EA glass. These releases are also predictable by the current durability models of the DWPF PCCS. A representation of predictability for ARM, EA and the SB7b Qualification Glass are in the plots for log normalized $\mathrm{B}, \mathrm{Li}, \mathrm{Na}$ and $\mathrm{Si}$ release as a function of $\Delta \mathrm{G}_{\mathrm{p}}$ as can be found in Table 4-4.

Table 4-4. PCT Results for ARM, EA and the SB7b Qualification Glass

\begin{tabular}{||c|c|c|c|c|c||}
\hline Glass ID & $\begin{array}{c}\text { NL (B) } \\
\mathbf{g} / \mathbf{L}\end{array}$ & $\begin{array}{c}\text { NL (Na) } \\
\mathbf{g} / \mathbf{L}\end{array}$ & $\begin{array}{c}\mathbf{N L ~ ( L i )} \\
\mathbf{g} / \mathbf{L}\end{array}$ & $\begin{array}{c}\mathbf{N L}(\mathbf{S i}) \\
\mathbf{g} / \mathbf{L}\end{array}$ & $\begin{array}{c}\text { NL (U) } \\
\mathbf{g} / \mathbf{L}\end{array}$ \\
\hline \hline ARM $^{\mathrm{a}}$ & 0.46 & 0.48 & 0.54 & 0.27 & N/A \\
\hline Est. Std. Unc. (1-Sigma) $^{\mathrm{b}}$ & 0.0037 & 0.0027 & 0.0035 & 0.0017 & N/A \\
\hline \hline EA $^{\mathrm{c}}$ & 16.60 & 13.36 & 9.56 & 3.96 & N/A \\
\hline Est. Std. Unc. (1-Sigma) $^{\mathrm{b}}$ & 0.0237 & 0 & 0.0421 & 0 & N/A \\
\hline \hline SB7b-QUAL $^{\mathrm{d}}$ & 0.77 & 0.92 & 0.91 & 0.61 & 0.38 \\
\hline Est. Std. Unc. (1-Sigma) $^{\mathrm{b}}$ & 0.0115 & 0.0134 & 0.0136 & 0.0088 & 0.0107 \\
\hline
\end{tabular}

${ }^{a}$ Average of 3 PCT replicates

${ }^{\mathrm{b}}$ Est. Std. Unc. - Estimated Standard Uncertainty

c Average of 2 PCT replicates

d Average of 4 PCT replicates 

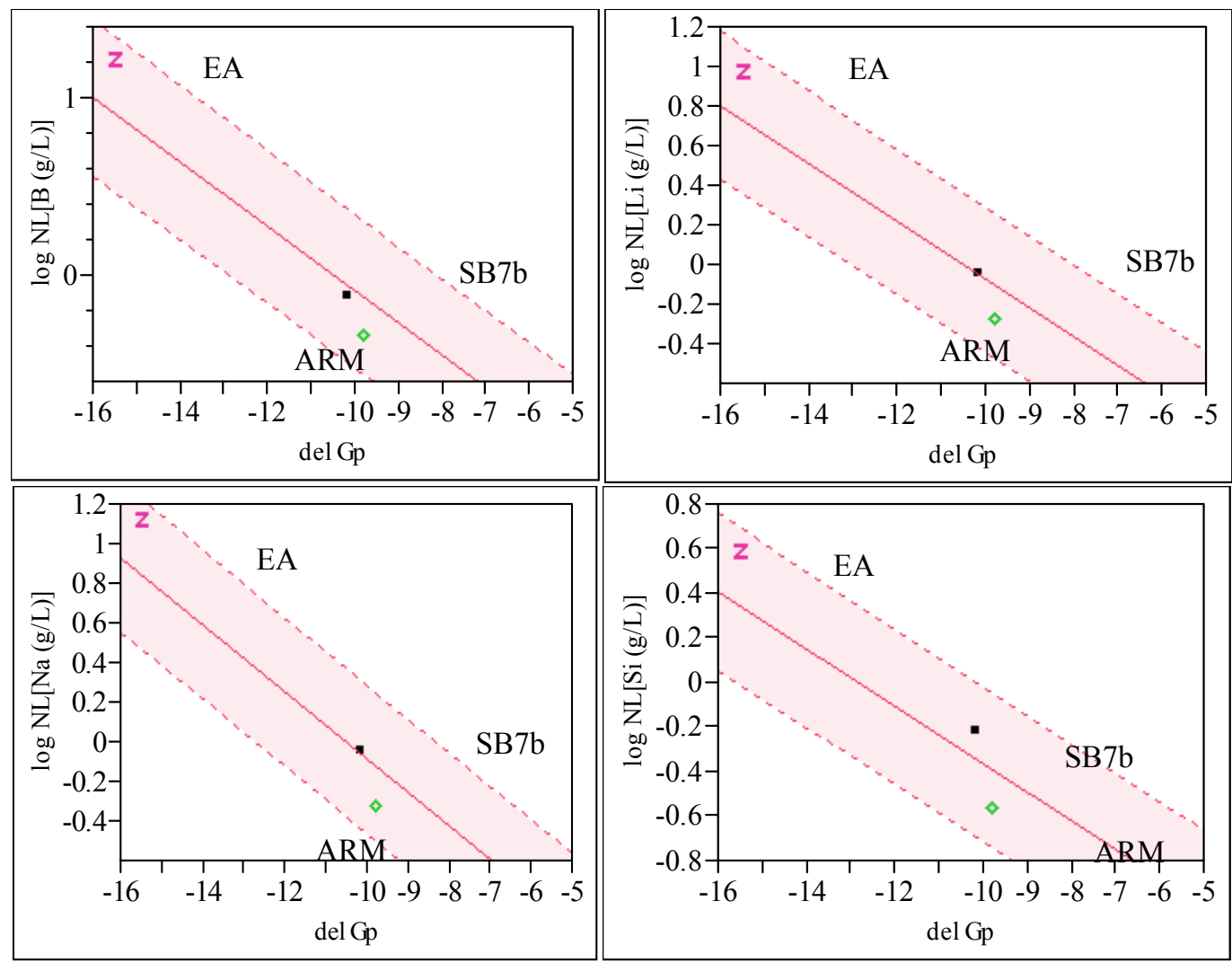

Figure 4-1. Fit of $\log$ Normalized Release of $\mathrm{B}, \mathrm{Li}, \mathrm{Na}$ and $\mathrm{Si}(\mathrm{g} / / \mathrm{L})$ vs. $\Delta \mathrm{G}_{\mathrm{p}}$ for the measured releases of ARM, EA and the SB7b Qualification glasses.

\subsection{Conclusions}

SRNL has completed qualification activities for SB7b. Characterization including radionuclide analyses was performed and reported. The CPC processes have been demonstrated and a glass has been fabricated and subjected to durability testing. The pertinent results of the testing were as follows:

- No new reportable elements or radionuclides were identified as part of the characterization.

- Rheological properties were acceptable for the SRNL prepared SRAT receipt and SRAT product. However, the measured yield stresses were near the upper operating limits for DWPF processing and the material appeared to be very tacky/sticky. At $>46 \mathrm{wt} \%$ total solids, the SME product had a very high consistency. It is recommended that DWPF not concentrate to this level.

- After adjusting the acid addition levels and further boiling, the SB7b Tank 40 qualification sample as prepared by SRNL met the processing constraints imposed by the DWPF. Mercury was removed to DWPF target levels after the first addition and boiling cycle (nominally 12 hours). Hydrogen generation rates were below the DWPF design bases throughout the SRAT and SME cycles. 
- Foaming was not problematic during SRAT and SME processing, and antifoam was effective when added. The antifoam was from Siovation Lot\#111128-0613. 300 ppm antifoam was added prior to acid addition; $100 \mathrm{ppm}$ antifoam was added after the initial nitric acid addition; $500 \mathrm{ppm}$ antifoam was added prior to boiling in Stage 1; and $100 \mathrm{ppm}$ additions were made at the start of each additional stage.

- The SB7b SME product (SB7b Tank 40 Qualification sludge plus Frit 702) was used to fabricate a glass with a targeted waste loading of $36 \%$. The glass was acceptable with respect to chemical durability as measured by the PCT. Specifically, the SB7b glass had a normalized boron release of $0.77 \mathrm{~g} / \mathrm{L}$, while the EA glass had a normalized release of 16.6 $\mathrm{g} / \mathrm{L}$. The PCT response was also predictable by the current durability models of the DWPF PCCS. 


\subsection{References}

1. Bricker, J. M. Technical Task Request Sludge Batch 7b Qualification Studies; HLWDWPF-TTR-2011-0004; Savannah River Site: Aiken, SC, 2011.

2. Pareizs, J. M. Task Technical and Quality Assurance Plan for Sludge Batch 7b Qualification in the Shielded Cells; SRNL-RP-2011-00247; Savannah River National Laboratory: Aiken, SC, 2011.

3. Pareizs, J. M. Analytical Study Plan for Sludge Batch $7 b$ Qualification in the Shielded Cells; SRNL-RP-2011-00248; savannah River National Lab: Aiken, SC, 2011.

4. $\quad$ E\&CPT Research Programs Section Procedure Manual; Manual L29; Savannah River National Lab: Aiken, SC, 2010.

5. Bibler, N. E. Measuring and Predicting Fission Product Noble Metals in Savannah River Site High Level Waste Sludges; WSRC-TR-2005-00098; Savannah River Site: Aiken, SC, 2005 .

6. $\quad$ Elder, H. H.; Ray, J. W. Estimated Quantity of C-14 in sludge Batch 7A Sludge Slurry; SRR-WSE-2011-00022; Savannah River Remediation, LLC.: Aiken, SC, 2011.

7. Darby, R., Chemical Engineering Fluid Mechanics, 2nd edition. Marcel Dekker: 2001.

8. Reboul, S. H.; Click, D. R. Stable Constituents In Sb7a Tank 40 WAPS Sample; SRNLL3100-2011-00133; Savannah River National Laboratory: Aiken, SC, 2011.

9. $\quad$ Pareizs, J. M.; Click, D. R. Sludge Batch 7a Tank 51 Confirmation Sample (HTF-51-1128) - As-Received Characterization; SRNL-L3100-2011-00051, Rev. 1; Savannah River National Laboratory: Aiken, SC, 2011.

10. Click, D. R.; Washington, A. L.; Pareizs, J. M. Tank 7 Sludge Batch 7b Qualification Sample Initial Characterization; SRNL-L4100-2011-00009, Rev. 1; Savannah River National Laboratory: Aiken, SC, 2011.

11. Pareizs, J. M. Sludge Batch 7a Tank 51 Confirmation Sample (HTF-51-11-28) - SRNLWashed Characterization; SRNL-L3100-2011-00099; Savannah River National Laboratory: Aiken, SC, 2011.

12. Pareizs, J. M. Chemical and Fissile Characterization Results of the SRNL-Prepared Sludge Batch $7 b$ Tank 51 and Tank 40 Samples; SRNL-L3100-2011-00128; savannah River National Laboratory: Aiken, SC, 2011.

13. Reboul, S. H.; Pareizs, J. M.; Click, D. R. Radionuclides in the Sb7b Qualification Sample Prepared at SRNL; SRNL-L3100-2011-00148; Savannah River National Laboratory: Aiken, SC, 2011.

14. Jantzen, C. M.; Stone, M. E. Role of Manganese Reduction/Oxidation (REDOX) on Foaming and Melt Rate in High Level Waste (HLW) Melters (U); WSRC-STI-200600066; Savannah River National Laboratory: Aiken, SC, 2007. 
15. Click, D. R. Determination of Oxalate Concentration in SB7b Sludge Slurry Feed and Experiments to Test for the Presence of Coal; SRNL-L4140-2011-00015; savannah River National Lab: Aiken, SC, 2011.

16. Koopman, D. C. Preliminary Evaluations of Two Proposed Stoichiometric Acid Equations; SRNL-L3100-2009-00146; Savannah River National Laboratory: Aiken, SC, 2009.

17. Basic Data Report: Defense Waste Processing Facility Sludge Plant; Savannah River Plant 200-S Area; DPSP-80-1033, Rev. 10; Savannah River Site: Aiken, SC.

18. Marek, J. C. Preliminary Melter Feed Rheology Study; WSRC-RP-92-01240; Westinghouse Savannah River Company: Aiken, SC, 1992.

19. Peeler, D. K.; Edwards, T. B. Frit and Waste Loading Recommendation for SB7b Qualification; Inter-Office Memorandum, SRNL-L3100-2011-00129; Savannah River National Laboratory: Aiken, SC, 2011.

20. Standard Test Methods for Determining Chemical Durability of Nuclear, Hazardous, and Mixed Waste Glasses and Multiphase Glass Ceramics: the Product Consistency Test (PCT); American Society for Testing and Materials (ASTM): West Conshohocken, PA, 2002.

21. Waste Acceptance Product Specification for vitrified High-Level-Waste Forms; Office of Environmental Management USDOE Document: 1996.

22. Jantzen, C. M.; Bibler, N. E.; Beam, D. C.; Crawford, C. L.; Pickett, M. A. Characterization of the defense waste processing facility (DWPF) environmental Assessment (EA) Glass Standard Reference Material; WSRC-TR-92-346; Savannah River Site: Aiken, SC, 1994.

23. Jantzen, C. M.; Pickett, M. A.; Brown, K. G.; Edwards, T. B.; Beam, D. C. Process/Product Models for the Defense Waste Processing Facility (DWPF): Part I. Predicting Glass Durability From Composition Using a Thermodynamic Hydration Energy Reaction Model (THERMO); WSRC-TR-93-0672; Savannah River Technology Center: Aiken, SC, 1993. 
SRNL-STI-2011-00548

Revision 0

Appendix A. Supplemental PCT Data 
Table A-1. PCT Elemental Releases and Measured pH for ARM, EA and the SB7b Qualification Glass

\begin{tabular}{||c|c|c|c|c|c|c|c|c||}
\hline \multirow{2}{*}{ Glass ID } & \multirow{2}{*}{$\mathbf{p H}$} & \multicolumn{6}{|c||}{ Elemental Release - Dilution Factor Corrected (ppm) } \\
\cline { 3 - 9 } & & $\mathbf{L i}$ & $\mathbf{B}$ & $\mathbf{N a}$ & $\mathbf{S i}$ & $\mathbf{F e}$ & $\mathbf{A l}$ & $\mathbf{U}$ \\
\hline \hline ARM-1-199 & 9.95 & 12.80 & 16.47 & 34.67 & 60.17 & N/A & 4.85 & N/A \\
\hline ARM-2-200 & 9.93 & 12.57 & 16.25 & 34.33 & 59.17 & N/A & 4.77 & N/A \\
\hline ARM-3-215 & 9.88 & 12.53 & 16.02 & 34.00 & 59.00 & N/A & 4.83 & N/A \\
\hline EA-1-125 & 11.54 & 188.33 & 581.67 & 1665.00 & 901.67 & $<0.64$ & $<2.22$ & N/A \\
\hline EA-2-188 & 11.58 & 190.00 & 583.33 & 1665.00 & 901.67 & $<0.64$ & 2.43 & N/A \\
\hline EA-3-195 & 11.59 & 12.78 & 17.00 & $<49.17$ & 60.50 & $<0.64$ & 5.77 & N/A \\
\hline SB7b-Qual-1-216 & 10.76 & 28.33 & 11.67 & 82.33 & 149.83 & 18.00 & 20.67 & 7.45 \\
\hline SB7b-Qual-2-220 & 10.74 & 28.17 & 11.70 & 81.67 & 143.50 & 17.00 & 20.33 & 8.20 \\
\hline SB7b-Qual-3-221 & 10.75 & 27.50 & 11.27 & 79.33 & 142.33 & 17.50 & 20.17 & 7.90 \\
\hline SB7b-Qual-4-222 & 10.71 & 29.33 & 11.88 & 84.33 & 148.83 & 17.33 & 20.50 & 7.23 \\
\hline
\end{tabular}


SRNL-STI-2011-00548

Revision 0

Appendix B. Flow Curves 

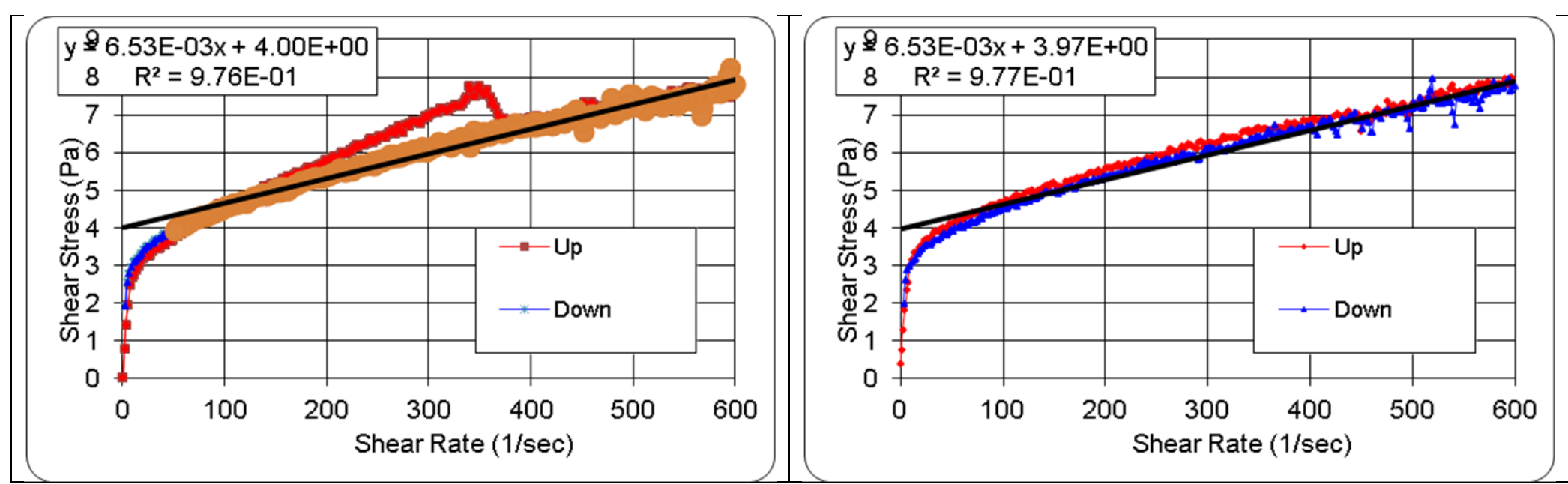

Figure B-1. SB7b SRAT Receipt Flow Curves 


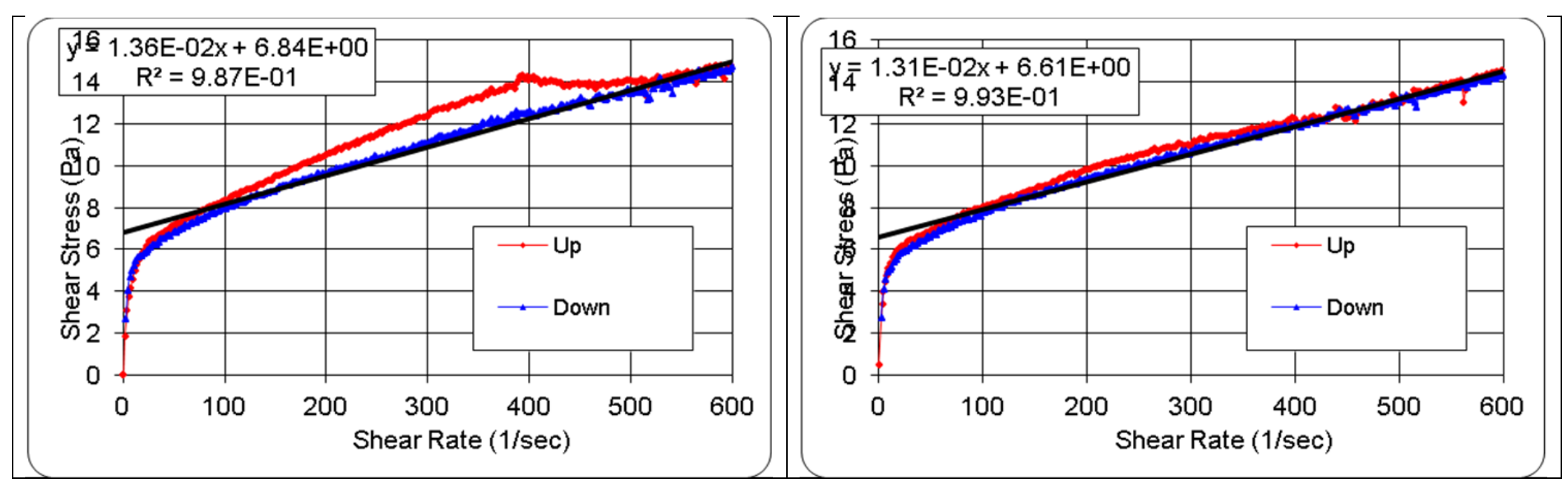

Figure B-2. SB7b SRAT Product Flow Curves 


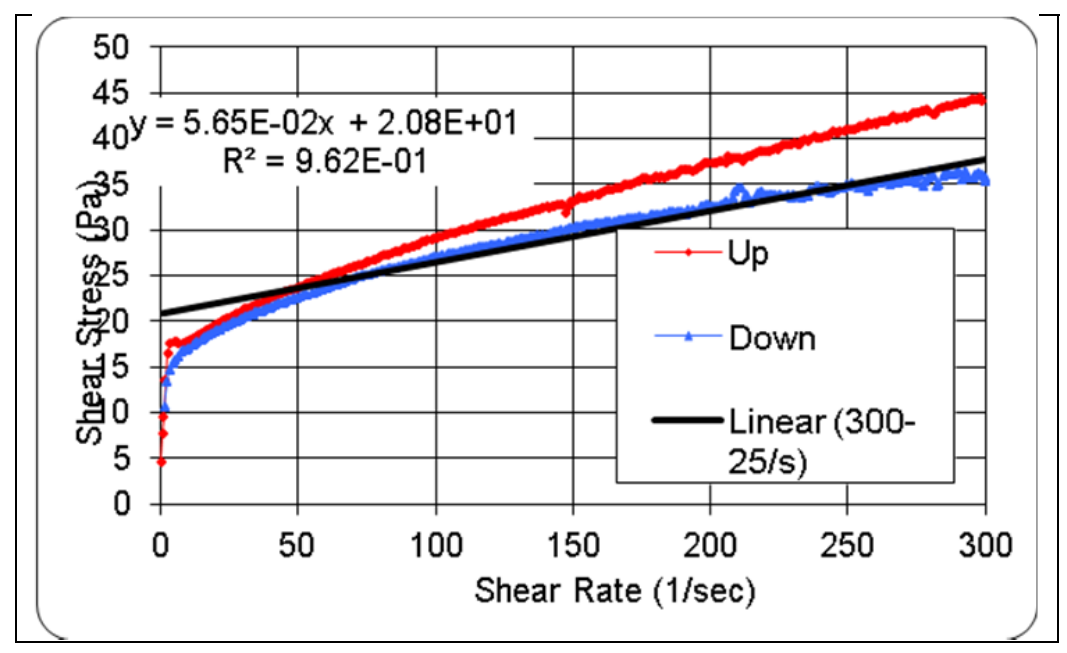

Figure B-3. SB7b SME Product Flow Curve 


\section{Distribution:}
A. B. Barnes, 999-W
C. E. Duffey, 704-61H
S. D. Fink, 773-A
M. A. Rios-Armstrong, 773-66A
B. J. Giddings, 786-5A
T. B. Edwards, 999-W
C. C. Herman, 999-W
D. C. Koopman, 999-W
S. L. Marra, 773-A
F. M. Pennebaker, 773-42A
K. M. Fox, 999-W
W. R. Wilmarth, 773-A
J. W. Amoroso, 999-W
J. M. Bricker, 704-27S
F. C. Johnson, 999-W
T. L. Fellinger, 704-26S
J. R. Zamecnik, 999-W
J. M. Gillam, 766-H
A. S. Choi, , 999-W
E. W. Holtzscheiter, 704-15S
H. Bui, 704-61H
J. F. Iaukea, 704-30S
D. J. Martin, 241-152H
M. T. Keefer, 766-H
C. M. Gregory, 773-A
D. W. Mcilmoyle, 766-H
J. E. Occhipinti, 704-S
D. K. Peeler, 999-W
J. W. Ray, 704-S
H. B. Shah, 766-H
D. C. Sherburne, 704-S
A. V. Staub, 704-27S
M. E. Stone, 999-W
P. R. Jackson, DOE-SR, 703-46A
K. H. Subramanian, 766-H
M. A. Broome, 704-29S
R. N. Hinds, 704-S
J. P. Vaughan, 773-41A 